\title{
Morphophysiological Investigations in Some Dominant Alien Invasive Weeds
}

\author{
Nivedita Ghayal ${ }^{1}$ and Kondiram Dhumal ${ }^{2}$ \\ ${ }^{1}$ Department of Botany, Abasaheb Garware College, Pune, M.S. \\ 2Department of Botany, University of Pune, Pune, M.S.
}

India

\section{Introduction}

Allelopathy generally refers to any direct or indirect, harmful or beneficial effect of one plant on other plants, animals including microorganisms, through the production of chemical compounds that are released into the environment (Rice 1984). These donor plants affect the germination, growth and development of the recipient plant species (Einhellig 1987). The science of allelopathy has a very crucial role in maintaining the phytodiversity / biodiversity of a particular region. In fact, the phenomenon of biodiversity is the reflection of allelopathic interactions in that area. The losses in phytodiversity which are taking place at an alarming rate throughout the world is mainly ascribed to introduction of invasive / alien species which substitute the native ones. Invaded plant species and their success as well as secret have always threatened the world's biodiversity.

"The invasive plants are also known as alien, exotic or introduced ones, which are new to a specific area, become dominant, replacing / substituting the native plant species". These wide-spreading, non-indigenous species adversely affect the habitats they are invading in. The most important aspect of the alien plant is their rapid growth, establishment over new and large areas. Introduced species often find no natural enemies in their new habitat and therefore spread easily and quickly, especially in open disturbed areas. Invasive plants reproduce fast, either vegetatively or by seed. Their phenomenal growth allows them to overwhelm and displace existing vegetation and form dense Monothickets.

\subsection{Ecological impacts of invasive plants on the environment}

The general ecological impacts of invasive plants on natives and their surrounding environment are given in nutshell:-

- Competition with (and/or replacement of) native plants along with rare and endangered once.

- Loss of habitat and food sources of native insects, birds, wildlife and plants including microorganisms.

- Disruption of native plant-animal associations

- Elimination of native plant communities

- Prevention of establishment of native plants

- Acute competition for space, water, sunlight and nutrients due to its reduction

- Change of the soil structure and chemistry 
- Morphophysiological interactions with native flora and fauna through release of allelochemicals / ecochemicals

\subsection{Scope of allelopathy}

At present it is well established that allelopathic phenomenon exist in different ecosystems including forest ecosystem and it can be exploited for increasing the productivity of crops as well as forest plant species in sustainable manner. According to Reigosa et al. (1999), allelopathy can affect distribution pattern of plants and biodiversity. They further explained that in a climax forest, germination and growth of understorey species must cope with allelochemicals released by the dominant trees. Those trees could release different chemicals, producing differences in the species composition. Similarly, Carballeira and Reigosa (1999) also indicated that monocultures (pure stands) allow the accumulation of particular allelochemicals affecting species composition. The occurrence of some weeds growing better than others within a monoculture could be a result of accumulation of allelochemicals. The allelopathic effects can affect small-scale vegetation patterns, by strengthening the associations between plants or not allowing them to grow in their vicinity. The research in allelopathy has increased greatly from 1960 onwards (Putnam 1985).

Inderjit et al. (2005a, b) has discussed in detail the challenges, achievements and opportunities in allelopathy research. They further highlighted that the novel research findings of allelopathy relevant to enzymes and genes involved in production of putative allelochemicals, allelochemical persistence in the rhizosphere, the molecular target sites of allelochemicals in sensitive plant species and the influence of allelochemicals upon other organisms will lead to enhanced utilization of natural products for pest management or as pharmaceuticals and nutraceuticals. The research and development in allelopathy is of extreme urgency for improvement of agriculture, forestry and global environment (Reigosa and Pedrol, 2002), because it deals majorly with invasive and native plant species.

\section{Allelobiogenesis - concept and mechanism}

Allelobiogenesis is nothing but the stress created by allelopathic effects of donor plants on recipient plants. In other words it is biotic stress and at the same time it is abiotic stress also. Allelobiogenesis is a typical stress combination of biotic and abiotic factors. Plant - plant, plant - animal and plant - micro-organism interactions can be considered as biotic stress.

The influence / stress of one plant on the other plant is mainly through the phytochemicals / ecochemicals / allelochemicals released by these donor plants. Hence the stress is obviously of abiotic nature. These allelochemicals are mainly secondary metabolites like alkaloids, glycosides, tannins, flavonoids, phenols etc. and the stress created by such allelochemicals is abiotic stress. The stress created by such allelopathic interaction or allelochemicals is allelobiogenesis. A weed exhausting nutrients from the soil voraciously and producing nutrient stress on associated crop as it shows dominance on associated crop by its faster growth and encroachment over crop species is biotic allelobiogenesis, e.g. Parthenium the invasive weed growing in association with Sorghum.

The exotic weed Parthenium is releasing large no. of allelochemicals through root exudation, leaching and volatilization in the surroundings and these allelochemicals cause very adverse effects on seed germination and growth and all the metabolic processes such as photosynthesis, respiration, absorption of water and minerals. This stress can be well explained as "abiotic allelobiogenesis". 
Weeds have many ill / negative characters, which cannot be neglected at all. Many of the weeds cause damages to agroecosystems and also disturb/ reduce natural phytodiversity. Weeds cause great harm to the crops in various ways as they cause $30-40 \%$ yield losses, increase the expenditure of various cultural practices, reduce the efficiency of agricultural implements. Perennial weeds reduce quality of fertile lands, cause obstacles for water flowing in canals. Weeds reduce crop yield and its quality as they compete with crops for resources like soil, water, nutrients and light. Weeds are alternative hosts for many pests and pathogens. Many weeds like Prosopis, Calotropis etc. reduce the germination capacity of crops' seeds due to the phytotoxins/ allelochemicals/ ecochemicals, many a times which are the secondary metabolites, secreted by them in the soil.

Aquatic weeds like Eichhornia and different types of algae produce toxins, which are harmful to aquatic flora and fauna. Weeds harbour organisms like mosquitoes, which cause or transmit diseases. Some weeds are poisonous to humans and produce pollens, which cause allergies. These studies will be more helpful, if emphasis on interactions among the plants is highly focused by the researchers. Studies on allelopathic potential and the biochemical characterization of native and invasive weeds has become the top priority to get rid of the ill effects of native and invasive weeds.

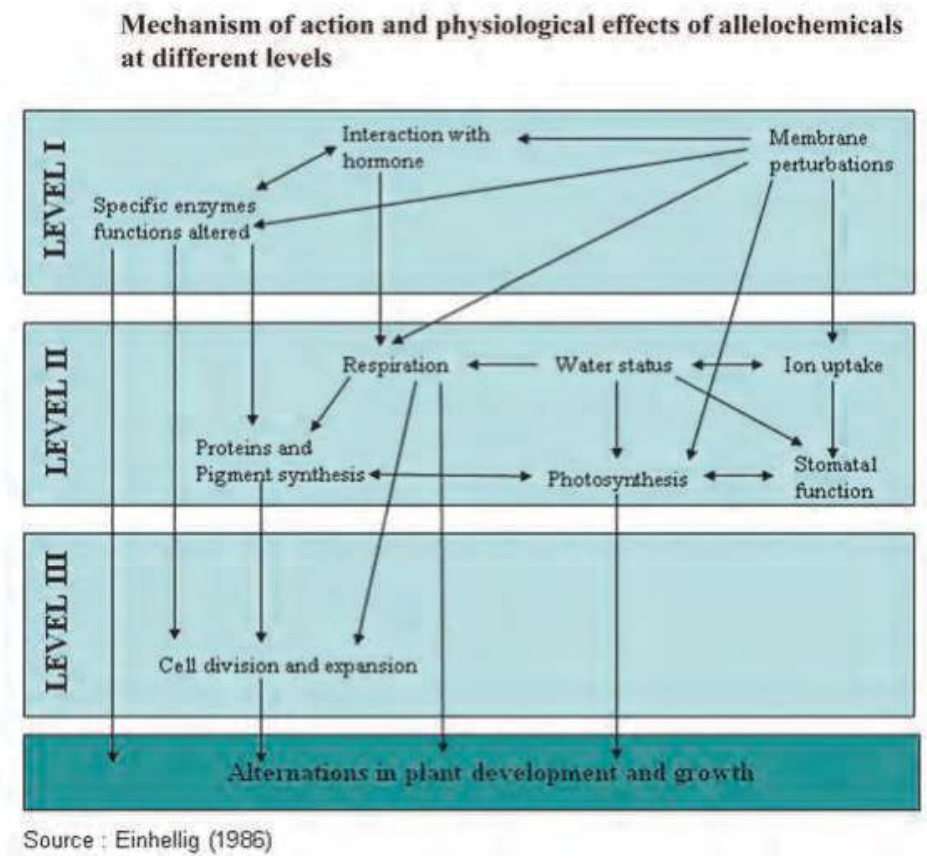

Diagram 1. Mechanism of action and physiological effects

\subsection{Allelopathic interactions between plants}

Allelopathic interactions are primarily based on the synthesis and release of secondary metabolites by higher plants that initiate a wide array of biochemical reactions, which induce several biological changes, however, many of these are yet to be understood. In 
nature, many plant species grow together and interact with each other by inhibiting or stimulating the growth and development through allelopathic interactions. In any ecosystem, the dominant plants growing within it are exhibited in the form of pure stands or monothickets. Such ecosystems always show the zones of inhibition around them (Nilsen 2002, Chase and Leibold 2003). The ecosystems infested by dominant weeds show drastic alterations in their structure and function.

All the weed species, which are the part of dynamic ecosystems, originate in natural environment and become hurdle to the crops (Aldrich 1984). These weeds have some diagnostic features, such as short seed dormancy period, high rate of seed germination, rapid seedling growth, high reproductive ability, life cycle of a short span, very high environmental plasticity, self-compatibility, effective and efficient methods of dispersal of propagules, production of different types of novel ecochemicals or allelochemicals and tolerance to biotic and abiotic stresses (Baker 1965), which enable them to grow and survive in varied habitats and inhospitable ecological conditions.

As a result of this these weeds are becoming dominant throughout the world (Colautti and MacIsaac 2004, Lee and Klasing 2004, Jeschke and Strayer, 2005). As stated by Li et al. (2009), the invasion of exotic weeds is mainly due to their easier establishment and faster growth under diverse environmental conditions. Lonsdale (1999) claimed that the propagules' pressure, adaptive characters and susceptible environment favour the invasibility to which Carlton (2001) called biological invasion.

\subsection{Plant invasions and encroachments}

The whole biosphere is facing the problem of invasion of different weed species, hence studies on plant invasions and allelopathy will help in understanding the mechanism of invasions, and consequences of them on global biodiversity and ecosystem functioning. These invasions pose many ecological, economic and social problems. A team approach to solve these complicated problems is necessary.

According to MacDougall and Turkington (2005), the alien species highly out compete the native species or escape from adverse environmental conditions and dominate the community. According to vacant niche hypothesis (Elton 1958) the empty places such as barren lands, roadsides, open grounds etc. are generally invaded by such weeds. There are different hypotheses explaining the invasion mechanisms (Inderjit et al. 2005a, b). The diversity of these weeds is governed by population, ecosystem dynamics, disturbances, nutrient supply and climatic factors. The biotic restrictions on them, force to skip from their previous habitat and start surviving in new habitats, helping in the process of invasion. The enemy release hypothesis advocated by Mack et al. (2000) also supports the above view. If the invader is resistant enough and tolerant to herbivory, then its competitive ability increases and it becomes very aggressive due to production of some defensive chemicals (Carpenter and Cappuccino 2005).

The disturbances by some plant species, grazing pressure, fluctuation in resource availability (Davis et al. 2000), soil moisture, available light (Meekins and Mc Carthy 2001), phenotypic plasticity and hybridization (Daehler 2003) results in to successful invasion. The novel weapon hypothesis (Callaway and Ridenour 2004), biotic resistance hypothesis (Maron and Vilà 2001), and the genetic shift hypothesis (DeWalt et al. 2004) also explain the mechanism of invasion. To understand the distribution of invasive weeds and their associates in a natural community, the eco-distribution mapping is of paramount importance. 
Biological species invasions alter ecological systems in a multitude of ways. Worldwide an estimated $80 \%$ of endangered species could suffer losses due to competition with or predation by invasive species.

\section{Compilation of updated work}

To have the information about the previous work done on allelopathy in general, its role in different fields of agriculture and botany, different types of interactions such as weed weed, weed - crop, the impact of leachates, extracts and residues on recipient plants, allelochemicals existing in different donor plants, their chemical structures, mode of release of these ecochemicals in the environment, their accumulation, mechanism of action, their effect on seed germination, seedling growth, mineral nutrition, microbial activity in the soil etc. a review of literature is given in nutshell.

Studies on allelopathy were made thousands of years before the term was coined by Molisch (1937). The term allelopathy is derived from two Latin words Allelon means each other and pathos means to suffer. He, for the first time studied the effect of numerous plant species and their plant parts viz.- roots, shoots, leaves, flowers, fruits, leachates, extracts and residues on seed germination, seedling growth and maturity of crops. Later on many scientists at different corners of the world, contributed to this field by carrying out the research on various aspects of allelopathy. At present the research on allelopathy is being carried out in more than 85 countries. In India, the research in this field took a great speed after 1950.

Vilai-Santisopasri (2003) studied the allelopathic effects of Eupatorium adenophorum Spreng. on growth of some crops and weeds. Hierro and Callaway (2003) had investigated in detail the invasion of exotic plants and their role in allelopathy. Many workers like Rice (1979), Gill and Sandhu (1996), Pawar and Chavan (1999), Chou (1999), Wang et al. (2001), Cheema et al. (2002) had great contribution in allelopathy through their basic research. Recently, many researchers like Narwal et al. (2003a, b), Podolska et al. (2003), Navaz et al. (2003), Batish et al. (2002), Singh and Singh (2003) and Azania et al. (2003) have introduced multidisciplinary approach in allelopathy.

According to Fujii et al. (2002) allelopathy now refers to any process involving secondary metabolites produced by plants, microorganisms, viruses and fungi, that influence the growth and development of agricultural and biological systems. The allelopathy workers like Bhatt and Chauhan (2000), Singh and NarsingRao (2003) and Leather and Einhellig (2005) also claimed that secondary metabolites produced by donor plants, when released into environment, play a key role in ecology and physiology of recipient plants. They further advocated that the released allelochemicals as well as the phytochemicals present in the leachates / extracts have stimulatory or inhibitory influence on seed germination, seedling growth and yield of recipient plants.

The allelopathic impact of invasive weeds on seed germination, seedling growth, growth parameters like plant height, number of leaves per plant, leaf area, yield contributing parameters like number of flowers and fruits per plant, weight of fruit and grains etc in different crops had been studied in detail by Rice (1979), Patil and Hegde (1988), Devi et al. (1997), Kulvinder et al. (1999), Bhalerao et al. (2000a, b), Wang et al. (2001), Kong and Hu (2001), Lin et al. (2002), Bhalerao (2003), Jadhav (2006), Hase (2008) and Vaidya (2009). Presently the allelopathy research work is mainly focused on identification of allelochemicals, their mode of action and ecological significance.

According to many researchers allelopathy now refers to any process involving secondary metabolites produced by plants, microorganisms, viruses and fungi that influence the 
Different pathways of synthesis of allelochemicals

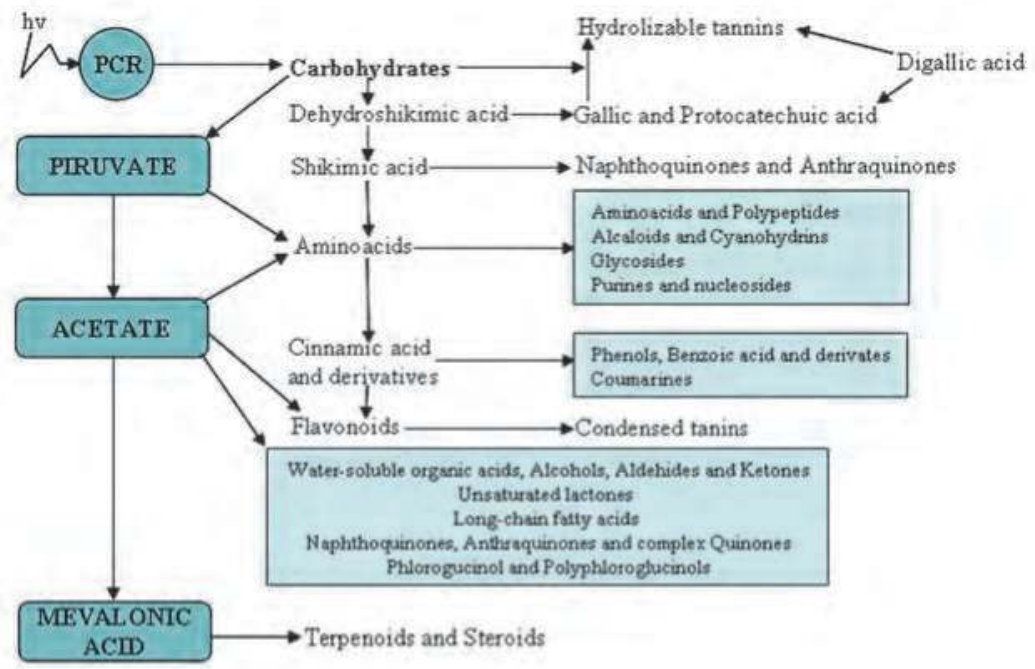

Source: Reigosa et al. (1999)

Induction of biosynthesis of allelochemicals.

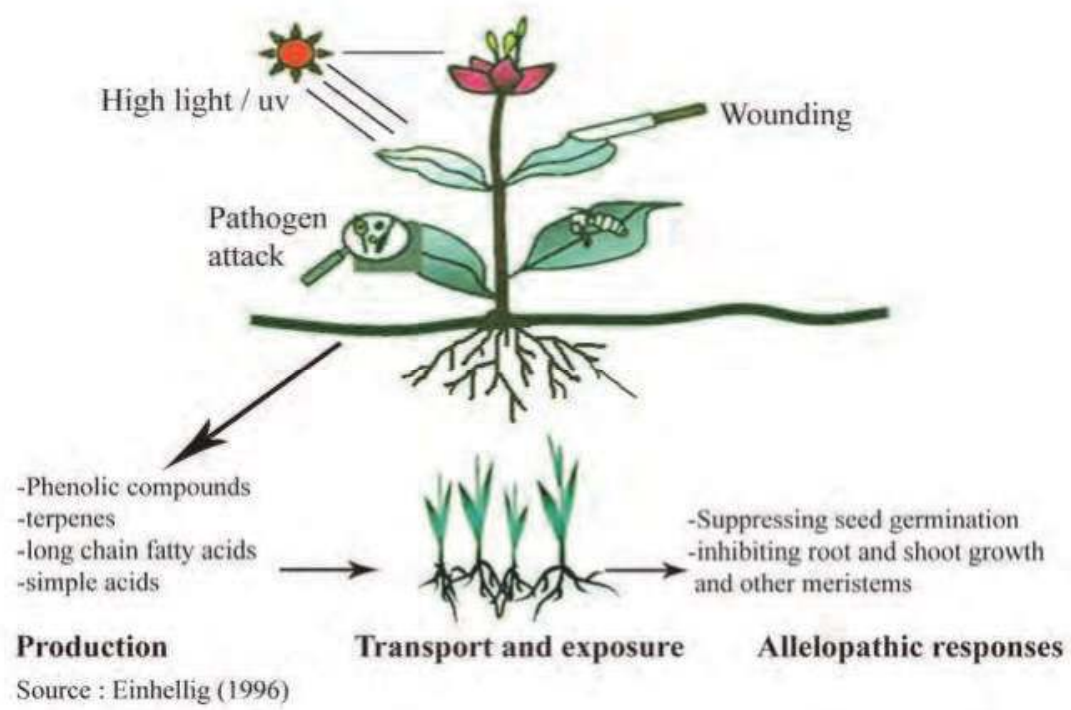

Diagram 2. Different pathways of synthesis of allelochemicals 
growth and development of agricultural and biological systems. The allelopathy workers also claimed that secondary metabolites produced by donor plants, when released into environment, play a key role in ecology and physiology of recipient plants. They further advocated that the released allelochemicals as well as the phytochemicals present in the leachates / extracts/ residues have stimulatory or inhibitory influence on seed germination, seedling growth and yield of recipient plants.

Today this subject has come into lime-light because of its multidisciplinary nature, which covers agriculture, biological sciences, biochemistry, physiology, biotechnology and even genetic engineering.

\subsection{Invasion success of weeds}

The light has been thrown on the success of invasive alien weeds outside their native boundary and probable causes of this. The biological processes and specific characteristics of invasive weeds are important factors in their introduction, spread, and establishment that threatens the ecosystems, habitats, or species with economic/ environmental harm. Therefore the detailed investigations on the ecological, physiological and molecular aspects of invasive weeds' allelopathy should be conducted in order to understand community structure and declining phytodiversity.

\subsection{Allelochemicals in invasive and native weed species}

Isolation, identification and characterization of allelochemicals present in roots, stems, leaves, flowers, fruits, seeds, bark, residues, litter, dried leaves (trash) and their leachates, extracts and residues have a pivotal role in allelopathy research, without which any predictions, possibilities, hypothesis and explanations are not possible. Asteraceae plants with their leachates, extracts and residues of different plant parts are well known for their allelopathic activity because of their allelochemicals like phenolic acids and terpenoids (Chon et al. 2003).

Many researchers like Ghayal et al. (2007a, b, c) and Li et al. (2009) have given prime importance for identification of allelochemicals, ecochemicals, novel bioactive compounds which are the secondary metabolites existing in their leachates, extracts and residues. They have characterized diverse groups of allelochemicals like terpenoids, flavonoids, phenolic compounds and essential oils existing in the invasive and native weeds.

\section{About the study area}

The big campus of University of Pune established in 1949, at Ganeshkhind occupies an area of 164.8 hectares, which is situated about seven km north-west of Pune city proper and lies between $18034^{\prime}$ North latitude and 73053' East longitude at an elevation of about $1880 \mathrm{~m}$. At present $1 / 4$ th area is occupied by roads, buildings and gardens.

Ganeshkhind stands on pediment surface of amygdaloidal basalt. These rocks are traversed by many veins and veinlets of silica and chalcedony. The poor soil of study area is reddish brown on higher grounds and deeper dark brown (black cotton soil) on flat areas. The soils are alkaline and are of pedocal type (Varadpande 1972). The average rainfall, climate and other environmental conditions of the campus are more or less similar to that of Pune city. The railfall is restricted to couple of months in monsoon and the maximum annual rainfall is $31.78 \mathrm{~cm}$. The temperature during hot season goes up to $40-42^{\circ} \mathrm{C}$ but normally it is cool as compared to Pune city. 


\subsection{Weed floristic of study area}

The phytosociological studies were conducted at all the four selected sites in Pune University campus. The different plant species were recorded with respect to their distribution, frequency, density and abundance. All four study sites (I to IV) showed the vegetation composition of various types of herbs, shrubs, trees, climbers and twinners.

The results on phytosociological studies at site I reported in Table 1 (a) indicated that this site was having highest weed diversity. The most abundant weeds at this site with maximum frequencies were Cassia uniflora (93.33\%), Achyranthes (90.00\%), Synedrella nodiflora $(90.00 \%)$ and Oplismenus (83.33\%). These were followed by Acalypha, Bidens, Boerhaavia and Euphorbia geniculata, all these were at par having frequency $(80.00 \%)$. Alternanthera tenella was also showing better population with frequency $76.67 \%$. Remaining native plants like Cynotis and Calotropis and invasive plants have shown less frequency, density and abundance.

The results of site II recorded Table 1(b) revealed that at this site, 43 different weed genera were recorded including about 19 genera of invasive weeds. The most abundant weeds with maximum frequencies were Synedrella nodiflora (96.67\%), Cassia uniflora (93.33\%), and Cassia absus $(86.67 \%)$. These were succeeded by Acalypha, Bidens and Euphorbia geniculata which were at par having frequency $(83.33 \%)$. Remaining plants showed discrete occurrence. At sites I and II Cassia uniflora was showing very thick population density, as these sites were exposed to sunlight for longer period.

The results on phytosociological studies of site III reported in Table 1 (c) illustrated that at this site, only 24 genera were reported including about 12 genera of invasive weeds. The plants recorded at this site in order of highest frequency were Synedrella nodiflora (93.33\%), Cassia uniflora $(80.00 \%)$ and Rauwolfia $(73.33 \%)$. As opposite to sites I and II, at site III, there was complete dominance of Synedrella nodiflora only, which was virtually forming monothickets / pure stands. Synedrella nodiflora being shade lover was showing luxuriant growth and very high dominance at this site. The shady conditions along with high soil moisture favoured the luxuriant growth of Synedrella nodiflora and Rauwolfia.

The results listed in Table 1 (d) regarding phytosociological studies carried out at site IV revealed that, there were about 32 genera of weed species including 14 genera of invasive weeds. The weeds with highest frequency were Cassia uniflora $(96.67 \%)$, Synedrella nodiflora (93.33\%) and Euphorbia geniculata (76.67\%), which were followed by Acalypha, Achyranthes and Alternanthera. At this site there was highest human interference as compared to the remaining three sites. The fast growing invasive weed Lantana camara showed successful invasion only at this site with frequency $63.33 \%$.

\begin{tabular}{|c|c|c|c|}
\hline No. & $\begin{array}{c}\text { Dominant } \\
\text { species }\end{array}$ & $\begin{array}{c}\text { Associated } \\
\text { species }\end{array}$ & $\begin{array}{c}\text { Nature of } \\
\text { association }\end{array}$ \\
\hline 1 & Cassia uniflora & Achyranthes aspera & Very common \\
\hline 2 & Cassia uniflora & Blainvillea acmella & Occasional \\
\hline 3 & Acalypha ciliata & Cassia uniflora & Rare \\
\hline 4 & Alternanthera tenella & Cassia uniflora & Common \\
\hline 5 & Synedrella nodiflora & Cassia uniflora & Common \\
\hline 6 & Oplismenus compositus & --- & Very common \\
\hline 7 & Euphorbia geniculata & Cassia uniflora & Common \\
\hline
\end{tabular}

Table 1. (a) Weed-weed interactions at site I in Pune university campus 


\begin{tabular}{|c|c|c|c|}
\hline No. & Dominant species & $\begin{array}{c}\text { Associated } \\
\text { species }\end{array}$ & $\begin{array}{c}\text { Nature of } \\
\text { association }\end{array}$ \\
\hline 1 & Bidens pilosa & Cassia uniflora & Very common \\
\hline 2 & Cassia uniflora & Achyranthes aspera & Very common \\
\hline 3 & Triumfetta rhomboidea & Cassia obtusifolia & Common \\
\hline 4 & Alternanthera tenella & Boerhaavia erecta & Common \\
\hline 5 & Cassia absus & Achyranthes aspera & Common \\
\hline 6 & Cassia uniflora & Synedrella nodiflora & Occasional \\
\hline 7 & Cassia uniflora & Parthenium hysterophorus & Rare \\
\hline
\end{tabular}

Table 1. (b) Weed-weed interactions at site II in Pune university campus

\begin{tabular}{|c|c|c|c|}
\hline No. & Dominant species & $\begin{array}{c}\text { Associated } \\
\text { species }\end{array}$ & $\begin{array}{c}\text { Nature of } \\
\text { association }\end{array}$ \\
\hline 1 & Synedrella nodiflora & Cassia uniflora & Very common \\
\hline 2 & Synedrella nodiflora & Achyranthes aspera & Common \\
\hline 3 & Cassia uniflora & Tithonia tagetiflora & Common \\
\hline 4 & Cassia uniflora & Achyranthes aspera & Common \\
\hline 5 & Rauwolfia tetraphylla & Euphorbia geniculata & Common \\
\hline
\end{tabular}

Table 1. (c) Weed-weed interactions at site III in Pune university campus

\begin{tabular}{|c|c|c|c|}
\hline No. & Dominant species & $\begin{array}{c}\text { Associated } \\
\text { species }\end{array}$ & $\begin{array}{c}\text { Nature of } \\
\text { association }\end{array}$ \\
\hline 1 & Cassia uniflora & Achyranthes aspera & Common \\
\hline 2 & Cassia uniflora & Alternanthera tenella & Common \\
\hline 3 & Lantana camara & Cassia uniflora & Occasional \\
\hline 4 & Acalypha ciliata & Cassia uniflora & Common \\
\hline
\end{tabular}

Table 1. (d) Weed-weed interactions at site IV in Pune university campus

Mishra et al. (1997), Chapin et al. (2000), Kumar et al. (2004), Jadhav (2006), Saswade (2007) and Thakur and Khare (2009) have also carried out the phytosociological studies on various invasive and native weeds. The phytosociological studies on Potentilla recta and other species, the invasive, noxious weed from Eurasia were carried out by Werner and Soule (1976). Zouhar (2003), Endress and Parks (2004) had also conducted phytosociological studies on these invasive weeds from U.S. The dominance of Cassia uniflora and Synedrella in the study area may be attributed to their aggressive nature, allelolpathic potential, adaptations in morphological and reproductive features along with specific type of physiological, biochemical and enzymological mechanisms allowing their faster growth and tolerance to biotic and abiotic stress conditions.

\subsection{Invasion components}

Along with the two dominant weed species like Cassia uniflora and Synedrella nodiflora at all the four sites, the major co-occuring species recorded were Acalypha ciliata, Boerhaavia erecta, Cassia obtusifolia, Lagasca mollis, Peristrophe bicalyculata, Parthenium hysterophorus and Triumfetta rhomboidea. The fact worth to mention was establishment of 
monothickets (Bhakat et al. 2006) of Cassia uniflora at sites I, II and IV and that of Synedrella at site III.

The results of GPS mapping of weeds in Pune University campus strongly support the phytosociological observations recorded through quadrat studies. The GPS mapping had given the exact latitude, longitude and altitude of each plant species. More than 200 waypoints were recorded to confirm the dominance of selected weed species like Cassia uniflora, Synedrella nodiflora, Alternanthera tenella, Bidens pilosa, Blainvillea acmella, Acalypha ciliata, Euphorbia geniculata, Triumfetta rhomboidea, Cassia obtusifolia etc. It has also indicated the dominance of Cassia uniflora and Synedrella nodiflora at all the four selected sites. These selected weeds were located at $18^{055^{\prime}}$ north latitude and $73^{\circ} 82^{\prime}$ east longitude and an altitude of $568.63 \mathrm{~m}$ and $571.48 \mathrm{~m}$ respectively.

The Millenium Ecosystem Assessment (2005) have claimed that invasive species are the most important drivers of ecosystem change, which can very well alter the vegetational set up of a particular area. Such phytosociological studies on various weeds occurring in crop ecosystems have been carried out by researchers like Bartariya et al. (2005) and Seal et al. (2009) have also reported the dominance of invasive weeds in different ecosystems.

\subsection{Secrets of invasion / encroachment and aggressiveness}

The invasive weeds can exploit many niches left available and keep changing the phytodiversity of these niches or ecosystems. Unless the phytosociological studies of such areas are carried out, it is difficult to know the extent of encroachment over natives and invasion by the invasive plants. Phytosociology will help to understand the growth characteristics, dominance, distribution and adaptations which enable these plants to sustain the changes in the environment. These studies help to determine the distribution, prevalence, competing ability, behaviour and survival of weeds (Rao, 2000). The results recorded in Tables $1(\mathrm{a}, \mathrm{b}, \mathrm{c}$ and $\mathrm{d})$ clearly showed the higher dominance of Cassia uniflora and Synedrella nodiflora, at different sites in the university campus amongst the co-occuring species. These two invasive weed species have caused the reduction in the native phytodiversity of Pune University campus. As suggested by Rizvi and Rizvi (1992), allelopathic interactions of these weeds might be playing a crucial role in existing vegetation pattern of Pune University campus.

The dominance of Cassia uniflora and Synedrella in the study area may be attributed to their aggressive nature, allelolpathic potential, adaptations in morphological and reproductive features along with specific type of physiological, biochemical and enzymological mechanisms allowing their faster growth and tolerance to biotic and abiotic stress conditions.

Plants are chemically well defended in their environments, because their exposure to any stress leads to the qualitative and quantitative changes in the plant biochemicals and enzymes as a part of defense mechanism. These defensive chemicals are nothing but allelochemicals only, which act as feeding deterrents or alter the physiology and development of the attacking organisms (Pathipati UshaRani 2008). Even the different organic compounds often have role in ecological development which mediates interactions between the donor plants and the recipient organisms. The defensive allelochemicals and organic compounds have crucial role in the weed-weed associations formed in the campus of Pune University. The allelopathic potential of invasive weeds like Cassia and Synedrella can be ascribed to the above mentioned factors. 
Allelochemicals always affect many aspects of plants' ecology e.g. distribution, growth, succession, structure of communities, dominance, diversity and productivity (Takeuchi et al. 2001). The population of Cassia uniflora had always shown its shifting nature, i.e. area with monothickets during first year will show very less population next year on the same spot. It may be due to the resource exhaust, autotoxicity and heavy accumulation of allelochemicals making the area inhospitable for its own growth. However, it requires further confirmation and experimentation in details.

\subsection{Morphological specifications of invasive and native weeds}

An attempt was made to study the morphological and reproductive features of invasive and native weeds from Pune university campus (Table 2). The maximum plant height was recorded for Cassia uniflora, $(104.66 \mathrm{~cm})$, which was followed by Triumfetta $(103.66 \mathrm{~cm})$ and Achyranthes $(96.33 \mathrm{~cm})$.

The root length indicates easy and proper establishment of the plants. The maximum root length was recorded for Alternanthera followed by Rauwolfia and Achyranthes.

The highest number of branches per plant was observed in Achyranthes and followed by Triumfetta, while the weed species like Acalypha and Oplismenus were without any branch. The number of branches in remaining weeds was next to the above weed species.

Cassia obtusifolia had maximum third leaf area and it was followed by Rauwolfia and Triumfetta. The third leaf area in remaining weeds was very less as compared to them.

The results on fresh biomass per plant indicated that Cassia obtusifolia was having highest biomass and Triumfetta was next to it. The weight of fresh biomass in the remaining weeds was comparatively very less.

The dry biomass per plant showed wide variations ranging from $0.89 \mathrm{~g}$ to $17.43 \mathrm{~g}$. The Cassia species e.g. C. obtusifolia and C. uniflora were having highest dry biomass $17.43 \mathrm{~g}$ and $12.4 \mathrm{~g}$ per plant respectively.

The highest fresh biomass per $\mathrm{m}^{2}$ area was recorded in Triumfetta, Cassia uniflora and Blainvillea. The remaining weeds recorded comparatively less biomass per $\mathrm{m}^{2}$ area in the campus of Pune University.

Many research workers like Sen (1977), Weaver and McWilliams (1980), Wilson (1988) had given due importance to morphological studies of native and invasive weeds. Ehrenfeld (2003) proposed that the invasive plants share many physical characteristics and tend to alter habitats. They have very high productivity and above ground biomass. They grow earlier in the season and show faster growth rate than native species. All such features might be applicable to Cassia and Synedrella, because of which they are dominant in the campus, showing luxuriant growth.

Unless we know the morphological features of weeds, the attempts for their effective management are difficult. With this view, Sutherland (2004) has described all the morphological details of different terrestrial and aquatic weeds of India. Similarly Monaco et al. (2002) had also investigated the various morphological characteristics of different weeds from USA. The life cycle of a plant can be understood well by its morphological structures, developmental processes and whole plant activities that occur during each phase of its life cycle. He further stated that selected phenotypes dominate their neighbours, because the timing of their life history optimizes their relative fitness and minimizes mortality. Same explanation may be true for the dominance of different invasive weeds including Cassia and Synedrella over the natives of Pune University campus. 


\begin{tabular}{|c|c|c|c|c|c|c|c|c|}
\hline $\begin{array}{l}\text { *Weed } \\
\text { spp. }\end{array}$ & $\begin{array}{c}\text { Plt. Ht. } \\
\mathrm{cm} .\end{array}$ & $\begin{array}{l}\text { Root } \\
\text { length } \\
\mathrm{cm} .\end{array}$ & $\begin{array}{c}\text { No. of } \\
\text { Branches/plt. }\end{array}$ & $\begin{array}{c}\text { No. of } \\
\text { leaves / } \\
\text { plt. }\end{array}$ & $\left|\begin{array}{c}\text { III Leaf } \\
\text { area } \\
\mathrm{cm}^{2}\end{array}\right|$ & $\begin{array}{c}\text { Fresh } \\
\text { biomass / } \\
\text { plt. g }\end{array}$ & $\begin{array}{c}\text { Dry } \\
\text { biomass } \\
\text { / plt. g }\end{array}$ & \begin{tabular}{|c} 
Fresh \\
biomass \\
$/ \mathrm{m}^{2}$ \\
$\mathrm{~g}$
\end{tabular} \\
\hline Cul & $\begin{array}{c}104.66 \\
a \pm 4.18\end{array}$ & $\begin{array}{c}17.66 \mathrm{c} \\
\pm 0.70\end{array}$ & $7 \mathrm{~d} \pm 0.28$ & $\begin{array}{c}18 \mathrm{e} \pm \\
0.4\end{array}$ & $\begin{array}{c}20.41 \mathrm{~d} \\
\pm 0.81\end{array}$ & $\begin{array}{c}36.3 \mathrm{~d} \pm \\
1.45\end{array}$ & $\begin{array}{c}12.4 \pm \\
0.49\end{array}$ & $\begin{array}{c}2316.2 \mathrm{~b} \\
\pm 92.64\end{array}$ \\
\hline Snl & \begin{tabular}{c|}
$63.66 \mathrm{e}$ \\
\pm 3.18 \\
\end{tabular} & $\begin{array}{c}17 \mathrm{c} \pm \\
0.85\end{array}$ & $8 c \pm 0.4$ & $31 \mathrm{a} \pm 1.5$ & $\begin{array}{c}14.9 \mathrm{e} \pm \\
0.74\end{array}$ & $\begin{array}{c}15.68 \mathrm{~g} \pm \\
0.78\end{array}$ & $\begin{array}{l}4.1 \pm \\
0.20\end{array}$ & $\begin{array}{l}282.42 \mathrm{f} \\
\pm 14.12\end{array}$ \\
\hline Alt & $\begin{array}{c}91 \mathrm{~b} \pm \\
6.37\end{array}$ & \begin{tabular}{|c|}
$22.66 \mathrm{a}$ \\
\pm 1.58
\end{tabular} & $9 b \pm 0.63$ & $\begin{array}{c}28 \mathrm{~b} \pm \\
1.96\end{array}$ & $\begin{array}{l}12.8 \text { ef } \\
\pm 0.89\end{array}$ & $\begin{array}{c}21.5 \mathrm{f} \pm \\
1.50\end{array}$ & $\begin{array}{l}8.3 \pm \\
0.58\end{array}$ & $\begin{array}{c}356.84 \mathrm{e} \\
\pm 24.98\end{array}$ \\
\hline Eug & \begin{tabular}{|c|}
$73.66 \mathrm{c}$ \\
\pm 2.20 \\
\end{tabular} & $\begin{array}{c}13.3 \mathrm{~d} \pm \\
0.39\end{array}$ & $3 \mathrm{~h}=$ & $\begin{array}{c}10 \mathrm{~g} \pm \\
0.3\end{array}$ & $\begin{array}{c}18.41 \mathrm{~d} \\
\pm 0.55\end{array}$ & $\begin{array}{c}19.06 \mathrm{f} \pm \\
0.57\end{array}$ & $\begin{array}{l}4.6 \pm \\
0.13\end{array}$ & $\begin{array}{c}114.36 \mathrm{~g} \\
\pm 3.43 \\
\end{array}$ \\
\hline Bod & $\begin{array}{c}46.33 \mathrm{~g} \\
\pm 2.77 \\
\end{array}$ & $\begin{array}{c}8.16 \mathrm{~g} \pm \\
0.48\end{array}$ & 4 & $15 \mathrm{f} \pm 0.9$ & $\begin{array}{c}11.8 \mathrm{fg} \\
\pm 0.70\end{array}$ & $\begin{array}{c}31.13 \mathrm{e} \pm \\
1.86\end{array}$ & $\begin{array}{c}10.7 \pm \\
0.64\end{array}$ & $\begin{array}{c}108.39 \mathrm{~g} \\
\pm 6.50\end{array}$ \\
\hline Ach & \begin{tabular}{c|}
$96.33 \mathrm{~b}$ \\
\pm 5.77 \\
\end{tabular} & $\begin{array}{c}20 \mathrm{~b} \pm \\
1.2\end{array}$ & $11 \mathrm{a} \pm 0.66$ & $\begin{array}{c}24 \mathrm{~d} \pm \\
1.44\end{array}$ & $\begin{array}{l}12.2 \mathrm{fg} \\
\pm 0.73\end{array}$ & $\begin{array}{c}34.72 \mathrm{~d} \pm \\
2.08\end{array}$ & $\begin{array}{c}10.2 \pm \\
0.61\end{array}$ & $\begin{array}{l}347.2 \mathrm{e} \\
\pm 20.83\end{array}$ \\
\hline Bln & \begin{tabular}{|c|}
66 de \pm \\
2.64
\end{tabular} & \begin{tabular}{|c|}
$5.5 \mathrm{~h} \pm$ \\
0.22
\end{tabular} & $6.33 \mathrm{e} \pm 0.25$ & $\begin{array}{c}7.33 \mathrm{~h} \pm \\
0.29\end{array}$ & $\begin{array}{c}13 \text { ef } \pm \\
0.52\end{array}$ & $\begin{array}{c}12.33 \mathrm{hi} \pm \\
0.49\end{array}$ & $\begin{array}{c}1.43 \pm \\
0.05\end{array}$ & $\begin{array}{c}579.51 \mathrm{c} \\
\pm 23.18\end{array}$ \\
\hline Aca & \begin{tabular}{|l|}
$49.66 \mathrm{f}$ \\
\pm 3.47 \\
\end{tabular} & $\begin{array}{c}4.5 \mathrm{hi} \pm \\
0.31 \\
\end{array}$ & $0 \mathrm{i} \pm 0$ & $\begin{array}{c}26 \mathrm{c} \pm \\
1.82\end{array}$ & $\begin{array}{c}10.5 \mathrm{~g} \pm \\
0.73\end{array}$ & $\begin{array}{c}9.33 \mathrm{i} \pm \\
0.65\end{array}$ & $\begin{array}{c}1.75 \pm \\
0.12\end{array}$ & $\begin{array}{c}171.67 \mathrm{~g} \\
\pm 12.01 \\
\end{array}$ \\
\hline Tum & \begin{tabular}{|c|}
103.66 \\
$a \pm 3.10$ \\
\end{tabular} & $\begin{array}{c}9.66 \mathrm{f} \pm \\
0.28\end{array}$ & 33 & $\begin{array}{c}25 \mathrm{~cd} \pm \\
0.75\end{array}$ & $\begin{array}{c}33.66 \mathrm{c} \\
\pm 1.00\end{array}$ & $\begin{array}{c}88.33 \mathrm{~b} \pm \\
2.64\end{array}$ & $\begin{array}{l}3.1 \pm \\
0.09\end{array}$ & $\begin{array}{c}2473.24 \mathrm{a} \\
\pm 74.19\end{array}$ \\
\hline $\mathrm{Cab}$ & $\begin{array}{c}52.26 \\
f g \pm 2.61\end{array}$ & $\begin{array}{c}11.4 \mathrm{e} \pm \\
0.57\end{array}$ & $8.33 c \pm 0.41$ & $\begin{array}{c}7.33 \mathrm{~h} \pm \\
0.36\end{array}$ & $\begin{array}{c}18.5 \mathrm{~d} \pm \\
0.92\end{array}$ & $\begin{array}{c}11.66 \mathrm{hi} \pm \\
0.58\end{array}$ & $\begin{array}{c}3.02 \pm \\
0.15\end{array}$ & $\begin{array}{c}139.92 \mathrm{~g} \\
\pm 6.99\end{array}$ \\
\hline $\mathrm{Cfl}$ & $\begin{array}{c}71.83 \\
\mathrm{~cd} \pm \\
2.15\end{array}$ & $\begin{array}{c}13.16 \mathrm{~d} \\
\pm 0.39\end{array}$ & 6.66 de \pm 0.19 & $\begin{array}{c}14.66 \mathrm{f} \pm \\
0.43\end{array}$ & $\begin{array}{c}45 \mathrm{a} \pm \\
1.35\end{array}$ & $\begin{array}{c}91.66 \mathrm{a} \pm \\
2.74\end{array}$ & $\begin{array}{c}17.43 \pm \\
0.52\end{array}$ & $\begin{array}{c}366.64 \mathrm{e} \\
\pm 10.99\end{array}$ \\
\hline Bdn & $\begin{array}{l}55.23 \mathrm{f} \\
\pm 3.31 \\
\end{array}$ & $\begin{array}{c}7.96 \mathrm{~g} \pm \\
0.47\end{array}$ & $8.33 c \pm 0.49$ & $\begin{array}{c}9.66 \mathrm{~g} \pm \\
0.57\end{array}$ & $\begin{array}{c}33.1 \mathrm{c} \pm \\
1.98\end{array}$ & $\begin{array}{c}12.9 \mathrm{gh} \pm \\
0.77\end{array}$ & $\begin{array}{c}2.35 \pm \\
0.14\end{array}$ & $\begin{array}{c}472.14 \mathrm{~d} \\
\pm 28.32\end{array}$ \\
\hline Raw & $\begin{array}{c}63 \mathrm{e} \pm \\
4.41\end{array}$ & $\begin{array}{c}20.76 \mathrm{~b} \\
\pm 1.45 \\
\end{array}$ & $5.33 \mathrm{f} \pm 0.37$ & $\begin{array}{c}20.33 \mathrm{e} \\
\pm 1.42\end{array}$ & $\begin{array}{c}42.66 \mathrm{~b} \\
\pm 2.98\end{array}$ & $\begin{array}{c}56.66 \mathrm{c} \\
\pm 3.96\end{array}$ & $\begin{array}{l}9.5 \pm \\
0.66\end{array}$ & $\begin{array}{c}396.62 \mathrm{e} \\
\pm 27.76\end{array}$ \\
\hline Opl & \begin{tabular}{c|}
$23.12 \mathrm{~h}$ \\
\pm 0.92 \\
\end{tabular} & $\begin{array}{c}3.2 . i \pm \\
0.12\end{array}$ & $0 \mathrm{i} \pm 0$ & $\begin{array}{c}10 \mathrm{~g} \pm \\
0.4\end{array}$ & $\begin{array}{c}3.5 \mathrm{~h} \pm \\
0.14\end{array}$ & $\begin{array}{c}5.35 \mathrm{j} \pm \\
0.21\end{array}$ & $\begin{array}{c}0.89 \pm \\
0.03\end{array}$ & $\begin{array}{c}112.35 \mathrm{~g} \pm \\
4.49\end{array}$ \\
\hline$p=$ & $<0.001$ & $<0.001$ & $<0.001$ & $<0.001$ & $<0.001$ & $<0.001$ & $<0.001$ & $<0.001$ \\
\hline
\end{tabular}

\# Data are the pooled means of three estimates each over two years tstandard deviation. 'p-value' denotes the significance of difference between the means by one way ANOVA statistics. a The values followed by different letters differ significantly by Duncan's multiple range test at $\mathrm{p}=0.05$.

* Cul: Cassia uniflora Mill.non Spreng ; Snl: Synedrella nodiflora(L) Gaertn; Alt: Alternanthera tenella Colla; Eug: Euphorbia geniculata Orteg.; Ach: Achyranthes aspera L.; Bod: Boerhaavia erecta L.; Bln: Blainvillea acmella L.; Aca: Acalypha ciliata Forsk.; Tum: Triumfetta rhomboidea Jacq.; Cab: Cassia absus L.; Cfl: Cassia obtusifolia L.; Bdn: Bidens biternata Lour.; Raw: Rauwolfia tetraphylla L.; Opl: Oplismenus compositus P.Beauv.

Table 2. Morphological features of invasive and native weeds

\subsection{Reproductive capabilities of invasive and native weeds}

The invasive and native weeds showed considerable variations in reproductive characters (Table 3 a). The type of inflorescence in majority of the weeds studied was mostly head, 
spike or cyme. Only in Euphorbia, it was cyathium, and in Oplismenus it was panicle. In almost all the weeds the inflorescence was axillary, but only in Achyranthes and Cassia absus, it was terminal.

For the number of inflorescences per plant Triumfetta, was at first rank, which was followed sequentially by Alternanthera, Synedrella and Cassia uniflora. The weed species like Blainvillea, Acalypha and Achyranthes were at medium position, while the least number was noted in Oplismenus.

The number of flowers, florets and flowerbuds per inflorescence was also a diagnostic feature for all the weeds. Acalypha was having highest number of male and female flowers together, whilst Achyranthes was following it (Table 3a). Oplismenus was in third position and it was followed by Synedrella. Remaining weeds had very few numbers of flowers/ florets/ flowerbuds and the lowest number of flowers was in Triumfetta.

The number of fruits per inflorescence is very important reproductive character which was in the order of -

Snl $>$ Ach $>$ Bdn $>$ Alt $>$ Tum $>$ Bln $>$ Aca $>$ Cul $>$ Cfl $>$ Cab $>$ Opl $>$ Eug $>$ Raw (Table 3b).

The number of seeds per plant was not showing the same order as that of number of fruits (Table $3 b$ ). This was due to the number of seeds per fruit, which is again a specific and variable character for a particular plant. The descending sequence for number of seeds per plant was:

$\mathrm{Cfl}>\mathrm{Snl}>\mathrm{Ach}>\mathrm{Cul}>\mathrm{Aca}>\mathrm{Bdn}>\mathrm{Tum}>\mathrm{Cab}>\mathrm{Alt}>\mathrm{Bod}>\mathrm{Bln}>\mathrm{Eug}>\mathrm{Opl}>\mathrm{Raw}$.

\begin{tabular}{|c|c|c|c|}
\hline $\begin{array}{c}\text { Weed } \\
\text { species }\end{array}$ & Type of Inflorescence & $\begin{array}{c}\text { No. of Inflo. / } \\
\text { plant }\end{array}$ & $\begin{array}{c}\text { No. of flowers, florets } \\
\text { or } \\
\text { floral buds per inflo. }\end{array}$ \\
\hline Cul & $\begin{array}{c}\text { Axillary raceme/ subsessile pairs, } \\
\text { Crowded upwards }\end{array}$ & $38.0 \mathrm{~d} \pm 1.52$ & $8.0 \mathrm{fgh} \pm 0.32$ \\
\hline Snl & Axillary heads & $60.0 \mathrm{c} \pm 3.00$ & $21.0 \mathrm{~cd} \pm 1.05$ \\
\hline Alt & Axillary clusters & $75.0 \mathrm{~b} \pm 5.25$ & $9.0 \mathrm{fgh} \pm 0.63$ \\
\hline Eug & Cyathium & $9.0 \mathrm{i} \pm 0.27$ & $8.0 \mathrm{fgh} \pm 0.24$ \\
\hline Bod & Umbels in terminal corymbose & $30.0 \mathrm{e} \pm 1.8$ & $13.0 \mathrm{efg} \pm 0.78$ \\
\hline Ach & Terminal spikes & $21.0 \mathrm{~g} \pm 1.26$ & $36.0 \mathrm{~b} \pm 2.16$ \\
\hline Bln & Heads in erect terminal cymes & $25.33 \mathrm{f} \pm 1.01$ & $13.0 \mathrm{efg} \pm 0.52$ \\
\hline Aca & Androgynous spikes & $23.0 \mathrm{fg} \pm 1.61$ & $178.3 \mathrm{a} \pm 12.48$ \\
\hline Tum & $\begin{array}{c}\text { Dense terminal and leaf opposed } \\
\text { cymes }\end{array}$ & $90.0 \mathrm{a} \pm 2.7$ & $4.0 \mathrm{~h} \pm 0.12$ \\
\hline Cab & Terminal raceme & $8.66 \mathrm{i} \pm 0.43$ & $14.0 \mathrm{ef} \pm 0.7$ \\
\hline Cfl & Axillary subsessile pairs of flowers & $9.33 \mathrm{i} \pm 0.27$ & $14.33 \mathrm{ef} \pm 0.42$ \\
\hline Bdn & Corymbose panicled heads & $15.66 \mathrm{~h} \pm 0.93$ & $16.66 \mathrm{de} \pm 0.99$ \\
\hline Raw & Umbelliform cyme & $9.66 \mathrm{i} \pm 0.67$ & $7.33 \mathrm{gh} \pm 0.51$ \\
\hline Opl & Panicle & $2.0 \mathrm{j} \pm 0.08$ & $24.0 \mathrm{c} \pm 0.96$ \\
\hline $\mathrm{p}=$ & & $<0.001$ & $<0.001$ \\
\hline
\end{tabular}

Table 3. (a) Reproductive features of invasive and native weeds 
The results on reproductive capacity of invasive and native weeds revealed that the highest reproductive capacity was recorded in Cassia obtusifolia, which was followed by Synedrella. While Achyranthes and Cassia uniflora were on the third rank. The least reproductive capacity was reported in Boerhaavia (Table 3b).

\begin{tabular}{|c|c|c|c|c|c|}
\hline $\begin{array}{c}\text { Weed } \\
\text { species }\end{array}$ & $\begin{array}{c}\text { No. of } \\
\text { fruits } \\
\text { inflo. }\end{array}$ & No. of fruits / plant & $\begin{array}{c}\text { No. of } \\
\text { seeds / } \\
\text { fruit }\end{array}$ & No. of seeds / plant & $\begin{array}{c}\text { Reproductive } \\
\text { Capacity }\end{array}$ \\
\hline Cul & 9 & $2736 \mathrm{f} \pm 109.44$ & 8 & $21888 \mathrm{~d} \pm 875.52$ & $18604 \mathrm{c} \pm 744.16$ \\
\hline Snl & 21 & $26460 \mathrm{a} \pm 1323$ & 1 & $26460 \mathrm{~b} \pm 1323$ & $23814 \mathrm{~b} \pm 1190.7$ \\
\hline Alt & 9 & $6075 \mathrm{~d} \pm 425.25$ & 1 & $6075 \mathrm{gh} \pm 425.25$ & $3037.5 \mathrm{fg} \pm 212.62$ \\
\hline Eug & 8 & $576 \mathrm{~h} \pm 17.28$ & 3 & $1728 \mathrm{k} \pm 51.84$ & $691.2 \mathrm{~h} \pm 20.73$ \\
\hline Bod & 13 & $5070 \mathrm{e} \pm 304.2$ & 1 & $5070 \mathrm{hi} \pm 304.2$ & $2028 \mathrm{~g} \pm 121.68$ \\
\hline Ach & 32 & $24192 \mathrm{~b} \pm 1451.52$ & 1 & $24192 \mathrm{c} \pm 1451.52$ & $19353.6 \mathrm{c} \pm 1161.21$ \\
\hline Bln & 13 & $4280.77 \mathrm{e} \pm 171.23$ & 1 & $4280.77 \mathrm{ij} \pm 171.23$ & $2996.539 \mathrm{fg} \pm 119.86$ \\
\hline Aca & 1 & $4100.9 \mathrm{e} \pm 287.063$ & 3 & $12302.7 \mathrm{e} \pm 861.18$ & $6679.89 \mathrm{e} \pm 467.59$ \\
\hline Tum & 12 & $4320 \mathrm{e} \pm 129.6$ & 2 & $8640 \mathrm{f} \pm 259.2$ & $3247.72 \mathrm{f} \pm 97.43$ \\
\hline Cab & 14 & $1697.36 \mathrm{~g} \pm 84.86$ & 4 & $6789.44 \mathrm{~g} \pm 339.472$ & $3394.72 \mathrm{f} \pm 169.73$ \\
\hline Cfl & 14 & $1915.91 \mathrm{fg} \pm 57.47$ & 32 & $62266.9 \mathrm{a} \pm 1868.007$ & $28020.11 \mathrm{a} \pm 840.60$ \\
\hline Bdn & 37 & $9653.14 \mathrm{c} \pm 579.18$ & 1 & $9653.14 \mathrm{f} \pm 579.18$ & $8205.05 \mathrm{~d} \pm 492.30$ \\
\hline Raw & 7 & $495.65 \mathrm{~h} \pm 34.6955$ & 2 & $991.309 \mathrm{k} \pm 69.39$ & $7183.4 \mathrm{e} \pm 502.83$ \\
\hline Opl & 24 & $1152 \mathrm{gh} \pm 46.08$ & 1 & $1152 \mathrm{k} \pm 46.08$ & $6220.8 \mathrm{e} \pm 248.83$ \\
\hline $\mathrm{p}=$ & & $<0.001$ & & $<0.001$ & $<0.001$ \\
\hline
\end{tabular}

Table 3. (b) Reproductive features of invasive and native weeds

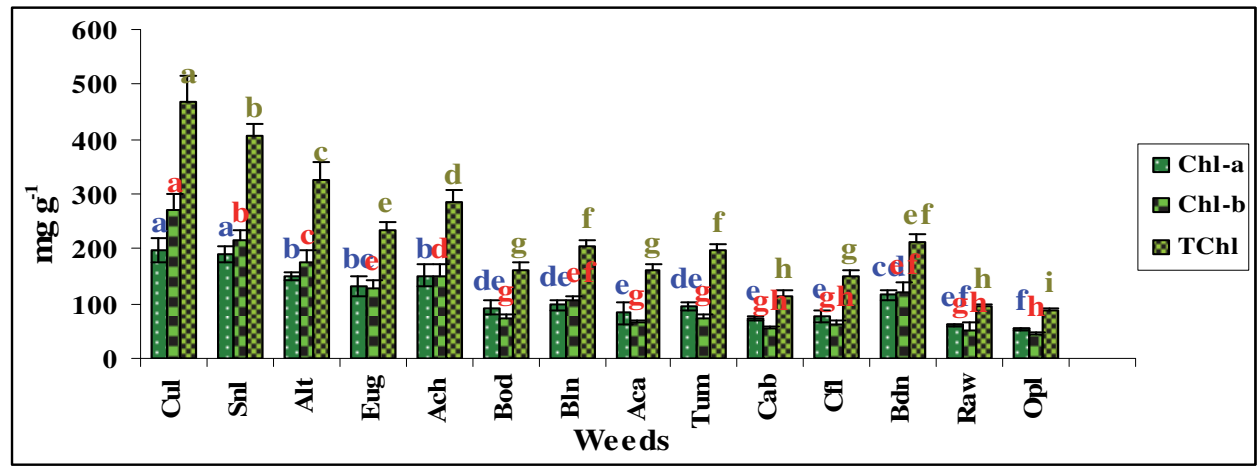

Fig. 1. Photosynthetic pigments in the invasive and native weeds

The role of reproductive capacity of weeds from arid zones was carried out by Sen (1981). Many researchers like Khanh et al. (2009) had studied the reproductive biology of Russian thistle, barnyardgrass, Solidago canadensis and Bidens pilosa respectively. Some have investigated the allelopathic potential of reproductive organs (flowers and fruits) of Lantana camara and explained their role in successful invasion, encroachment and dominance of it. 
The role of reproductive capacity of weeds from arid zones was carried out by Sen (1981) and Kanchan and Jayachandra (1977) for Parthenium hysterophorus. The seed output and other propagules was studied by Stevens (1957) for different weed species. Many researchers like Young (1991), Norris (1992), Huang Hua et al. (2007) and Khanh et al. (2009) had studied the reproductive biology of Russian thistle, barnyardgrass, Solidago canadensis and Bidens pilosa respectively. Hu and Wang (2001) studied the reproduction of two weedy vines. Qiaoying Zhang et al. (2009) had investigated the allelopathic potential of reproductive organs (flowers and fruits) of Lantana camara and explained their role in successful invasion, encroachment and dominance of it.

The reproductive characters are the probable indicators of plants' invasiveness and aggressiveness in the ecosystem. Not only this, but they are also the factors deciding their density and abundance. Dekker (2005) had also opined similarly indicating the role of reproductive features in plant invasion. Bhan et al. (1976) also emphasized on the role of reproductive behavior of Phalaris minor in its dominance and invasion. In the present study also, the comparison made on the basis of morphological and reproductive characters between invasive and native weeds revealed that the selected invasive weeds were superior in all the above-mentioned features, reflecting on their dominance over natives in the campus of Pune University. Friedman and Waller (1983) also stated that the seeds of plants act as allelopathic agents, releasing the different types of allelochemicals in their surrounding environment and which help to establish their dominance.

\subsection{Light harvesting components in invasive and native weeds}

The results shown in Figure 1 revealed that amongst invasive weeds Cassia uniflora and Synedrella had higher chlorophyll a, b and total chlorophyll contents, followed by Alternanthera. Amongst invasive weeds Bidens and Blainvillea are at par for chlorophyll contents. Amongst the natives Triumfetta was following Achyranthes for photosynthetic pigments. Remaining invasive and native weeds were at intermediate state for the contents of photosynthetic pigments. Whilst, Oplismenus and Rauwolfia had shown the lowest chlorophyll contents. The invasive weeds like Cassia uniflora, Synedrella and Alternanthera had shown maximum amount of chlorophyll $a$, chlorophyll $b$ and total chlorophylls.

The results recorded on photosynthetic pigments in different invasive and native weeds were corroborating with that of photosynthetic rate and other gas exchange parameters (Table 4 and Figure 1). Ghayal et al. (2009) have quantified the photosynthetic pigments in different invasive, native, aquatic as well as terrestrial weeds. Pawar (2004), Jadhav (2006), Castillo et al. (2007), Vaidya (2009) have quantified the photosynthetic pigments in different invasive, native, aquatic as well as terrestrial weeds. Wang et al. (2004) also recorded significant contents of chlorophylls and better photosynthetic rate in Eupatorium. Bhalerao (2003) had made similar observations regarding photosynthetic pigments in fern species like Tectaria and Pteridium from Mahabaleshwar area.

Photosynthetic pigments are the master molecules in carbon assimilation process, which govern photosynthetic efficiency. Sampietro et al. (2007) explained that the growth, development, dominance and allelopathic potential of any plant species mostly depend on its physiological, biochemical and enzymological characteristics. The growth, development, dominance and allelopathic potential of any plant species mostly depend on its physiological, biochemical and enzymological characteristics. The allelochemicals in it are also important along with above aspects. The amount of photosynthetic pigments usually correlates with photosynthetic rate, which is directly or indirectly reflected into 
accumulation of reserved food materials like starch and dry matter accumulation rate and dry biomass. Considering this the dominance of Cassia, Synedrella and other native weeds can be correlated with higher amount of chlorophyll contents, enhanced photosynthetic rate and increased accumulation of reserved food materials.

\subsection{Carbon assimilation rate of invasive and native weeds}

The selected invasive weeds like Cassia, Synedrella and Alternanthera had shown the highest photosynthetic rate, stomatal conductance and transpiration rate as compared to native weeds such as Achyranthes and Boerhaavia (Table 4). Amongst the natives Achyranthes was superior in all above mentioned parameters over other weeds like Triumfetta, Boerhaavia, Cassia absus and Rauwolfia.

The third leaf area was maximum in Cassia obtusifolia, which was followed by Rauwolfia and Triumfetta. There was no significant difference in water use efficiency (WUE) amongst the investigated invasive and native weeds. On the basis of dry matter accumulation rate (DMAR) Cassia uniflora was topmost, which was followed by Synedrella and Alternanthera. Similarly the results for dry weight per plant (Table 4) indicated highest values for Cassia obtusifolia followed by Cassia uniflora and Boerhaavia.

According to McDowell (2002) the success of invasion and dominance of invasive weeds in any ecosystem over co-occurring species can be ascribed to their superiority in physiological attributes like photosynthetic rate, stomatal conductance, third leaf area and DMAR, but all such parameters mostly remained unexplained and unexplored. Understanding of such factors may give valuable insight to resolve the problem of invasion. Photosynthesis is the key catabolic process in the life cycle of any plant, which synthesizes various types of photoassimilates and reflects into overall productivity and metabolic status of that plant. The secondary metabolites acting as allelochemicals are mainly derived from carbohydrates synthesis during photosynthesis.

Research workers like Durand and Goldstein (2001) and Ewe and Sternberg (2003) have also recorded the significant difference in photosynthetic rate, stomatal conductance, transpiration rate and total leaf area for the various invasive weeds and claimed that these weeds were highly dominant over the associated natives because of their superiority in above parameters.

According to Pattison et al. (1998) successful invasive species should have elite morphological and physiological traits, which increase their photon capturing ability and light utilization efficiency. But unfortunately this type of invagination has remained obscure due to paucity of experimental work, except few reports on light capturing mechanism, photon-saturated photosynthetic rate, specific leaf area (SLA) investigated in some invasive weeds by Ewe and Sternberg (2003). According to Durand and Goldstein (2001) invasiveness of alien species is dependent on photosynthetic efficiency. They further claimed that invasive species have a higher ability to capture solar radiations at the minimum cost of energy (ATP), diverting more resources for their growth, development, reproduction and yield. Coupled with the above distinctive features of photosynthesis, the invasive weeds have very high abiotic stress tolerance capacity, which enables them to survive and reproduce successfully, under extremely harsh environmental conditions like drought.

The water use efficiency (WUE) is always positively co-related with the rate of photosynthesis, however in present studies it has not shown any significant differences, 
amongst the invasive and native weed species investigated. Funk and Vitousek (2007) have reported the positive co-relation with leaf traits and WUE in some weeds. Blicker et al. (2003) had also reported higher water use efficiency in the invasive weed Centaurea maculosa over three native grasses.

\begin{tabular}{|c|c|c|c|c|c|c|c|}
\hline $\begin{array}{l}\text { Weed } \\
\text { Sps. }\end{array}$ & $\left|\begin{array}{c}\text { Photosynthetic } \\
\text { rate } \\
\mu \mathrm{mol} \mathrm{cm} \mathrm{cm}^{-2} \mathrm{sec}^{-1}\end{array}\right|$ & $\begin{array}{c}\text { Stomatal } \\
\text { conductance } \\
\mathrm{mmol} \mathrm{cm}^{-2} \mathrm{sec}^{-1}\end{array}$ & $\begin{array}{c}\text { III } \\
\text { leaf area } \\
\mathrm{cm}^{2}\end{array}$ & $\begin{array}{l}\text { Transp. rate } \\
\text { mmol } \\
\mathrm{cm}^{-2} \mathrm{sec}^{-1}\end{array}$ & $\begin{array}{c}\text { WUE } \\
\mu \mathrm{molm} \\
\mathrm{mol}^{-1}\end{array} \mid$ & $\begin{array}{c}\text { DMAR } \\
/ \mathrm{m}^{2} / \\
\text { day }\end{array}$ & $\begin{array}{c}\text { Dry } \\
\text { weight } \\
\text { / plant } \\
\text { g }\end{array}$ \\
\hline Cul & $29.55 \mathrm{a} \pm 4.84$ & $0.353 a$ & \begin{tabular}{c|}
$20.41 \mathrm{~d}$ \\
\pm 0.82
\end{tabular} & $\begin{array}{l}1.181 \mathrm{a} \\
\pm 0.21\end{array}$ & \begin{tabular}{r|}
25.02 \\
\pm 1.00 \\
\end{tabular} & $\begin{array}{c}19.16 \mathrm{a} \pm \\
0.77\end{array}$ & $\begin{array}{c}12.40 \mathrm{~b} \\
\pm 0.50 \\
\end{array}$ \\
\hline Snl & $\begin{array}{c}29.122 \mathrm{ab} \pm \\
6.15 \\
\end{array}$ & $0.351 \mathrm{ab} \pm 0.038$ & $\begin{array}{c}14.90 \mathrm{e} \pm \\
0.75\end{array}$ & $\begin{array}{c}1.152 \mathrm{ab} \\
\pm 0.242\end{array}$ & \begin{tabular}{|c|}
25.28 \\
\pm 1.26 \\
\end{tabular} & $\begin{array}{l}5.90 \mathrm{~b} \\
\pm 0.30 \\
\end{array}$ & $\begin{array}{r}4.10 \mathrm{~g} \\
\pm 0.21 \\
\end{array}$ \\
\hline Alt & $27.3 \mathrm{ab} \pm 0.43$ & $0.34 a \pm 0.072$ & $\begin{array}{c}12.80 \mathrm{ef} \\
\pm 0.90 \\
\end{array}$ & $\begin{array}{c}1.053 \mathrm{abc} \\
\pm 0.13\end{array}$ & $\begin{array}{r}25.93 \\
\pm 1.81 \\
\end{array}$ & $\begin{array}{r}4.18 \mathrm{c} \\
\pm 0.29 \\
\end{array}$ & $\begin{array}{r}8.30 \mathrm{f} \\
\pm 0.58 \\
\end{array}$ \\
\hline Eug & $\begin{array}{c}27.137 \mathrm{ab} \pm \\
3.06\end{array}$ & $0.318 \mathrm{a} \pm 0.027$ & $\begin{array}{c}18.41 \mathrm{~d} \pm \\
0.55\end{array}$ & $\begin{array}{c}1.048 \mathrm{bcd} \\
\pm 0.033\end{array}$ & \begin{tabular}{|c|}
25.89 \\
\pm 0.78 \\
\end{tabular} & $\begin{array}{l}2.66 \mathrm{~d} \\
\pm 0.08 \\
\end{array}$ & $\begin{array}{l}4.60 \mathrm{~g} \\
\pm 0.14 \\
\end{array}$ \\
\hline Ach & $\begin{array}{c}27.237 \mathrm{ab} \pm \\
2.01\end{array}$ & $0.324 a \pm 0.027$ & $\begin{array}{c}12.20 \mathrm{fg} \\
\pm 0.73 \\
\end{array}$ & $\begin{array}{c}1.052 \mathrm{abc} \\
\pm 0.095\end{array}$ & & $\begin{array}{l}2.58 \mathrm{~d} \\
\pm 0.15 \\
\end{array}$ & $\begin{array}{l}10.20 \mathrm{~d} \\
\pm 0.61\end{array}$ \\
\hline Bod & $22.1 b c \pm 3.79$ & $0.256 \mathrm{~b}$ & $\begin{array}{c}11.80 \mathrm{fg} \\
\pm 0.71 \\
\end{array}$ & $\begin{array}{c}0.874 \text { cde } \\
\pm 0.16\end{array}$ & \begin{tabular}{|r|}
25.29 \\
\pm 1.52 \\
\end{tabular} & $\begin{array}{l}2.62 \mathrm{~d} \\
\pm 0.16 \\
\end{array}$ & $\begin{array}{c}10.70 \mathrm{~cd} \\
\pm 0.64\end{array}$ \\
\hline$B \ln$ & $\begin{array}{c}23.308 \text { bc } \pm \\
8.59\end{array}$ & $0.272 b c \pm 0.10$ & $\begin{array}{c}\begin{array}{c}13.00 \mathrm{ef} \\
\pm 0.52\end{array} \\
\end{array}$ & $\begin{array}{r}0.96 \\
\pm \\
\end{array}$ & \begin{tabular}{|c|}
24.08 \\
\pm 0.96 \\
\end{tabular} & $\begin{array}{c}0.46 \mathrm{gh} \pm \\
0.02\end{array}$ & $\begin{array}{c}1.43 \mathrm{jk} \pm \\
0.06\end{array}$ \\
\hline Aca & $\begin{array}{c}21.833 \mathrm{bc} \pm \\
0.45\end{array}$ & $0.253 \mathrm{bcd} \pm 0.006$ & $\begin{array}{c}10.50 \mathrm{~g} \pm \\
0.73\end{array}$ & 0.845 cde \pm 0.020 & \begin{tabular}{|r|}
25.84 \\
\pm 1.81 \\
\end{tabular} & $\begin{array}{c}0.85 \mathrm{fg} \pm \\
0.06\end{array}$ & $\begin{array}{l}1.75 \mathrm{ij} \\
\pm 0.12 \\
\end{array}$ \\
\hline Tum & $22.483 b c \pm 5.01$ & $0.266 b c \pm 0.058$ & $\begin{array}{c}33.66 \mathrm{c} \pm \\
1.01\end{array}$ & $\begin{array}{c}0.88 \\
\pm \\
\end{array}$ & \begin{tabular}{|c|}
25.29 \\
\pm 0.76 \\
\end{tabular} & $\begin{array}{l}1.46 \mathrm{e} \\
\pm 0.04 \\
\end{array}$ & $\begin{array}{c}11.35 \mathrm{c} \pm \\
0.34\end{array}$ \\
\hline $\mathrm{Cab}$ & $19.5 c \pm 0.7$ & 0.178 de \pm 0.014 & $\begin{array}{c}18.83 \mathrm{~d} \pm \\
0.94\end{array}$ & 0.731 def \pm 0.038 & \begin{tabular}{|c|}
26.68 \\
\pm 1.33 \\
\end{tabular} & $\begin{array}{l}0.26 \mathrm{~h} \\
\pm 0.01 \\
\end{array}$ & $\begin{array}{l}3.02 \mathrm{~h} \\
\pm 0.15 \\
\end{array}$ \\
\hline $\mathrm{Cfl}$ & $21.533 b c \pm 0.51$ & $0.21 \mathrm{cde}=$ & $\begin{array}{c}45.00 \mathrm{a} \pm \\
1.35\end{array}$ & 0.832 cde \pm 0.032 & \begin{tabular}{|c|}
25.88 \\
\pm 0.78 \\
\end{tabular} & $\begin{array}{c}0.58 \mathrm{gh} \pm \\
0.02\end{array}$ & $\begin{array}{c}17.43 \mathrm{a} \pm \\
0.52\end{array}$ \\
\hline Bdn & $26.542 \mathrm{ab} \pm 3.88$ & $0.309 a \pm$ & $\begin{array}{c}33.10 \mathrm{c} \pm \\
1.99\end{array}$ & $\begin{array}{l}1.016 \mathrm{bcd} \\
\pm 0.15\end{array}$ & \begin{tabular}{|c|}
26.12 \\
\pm 1.57 \\
\end{tabular} & $\begin{array}{c}1.09 \mathrm{ef} \pm \\
0.07\end{array}$ & $\begin{array}{c}2.35 \mathrm{hi} \pm \\
0.14\end{array}$ \\
\hline Raw & $17.867 \mathrm{c} \pm 1.53$ & $0.143 e \pm 0.033$ & $\begin{array}{c}42.66 \mathrm{~b} \pm \\
2.99\end{array}$ & $\begin{array}{l}0.702 \text { ef } \\
\pm 0.0603\end{array}$ & \begin{tabular}{|c|}
25.45 \\
\pm 1.78 \\
\end{tabular} & $\begin{array}{l}0.32 \mathrm{~h} \\
\pm 0.02\end{array}$ & $\begin{array}{l}9.50 \mathrm{e} \\
\pm 0.66\end{array}$ \\
\hline Opl & $15.283 d \pm 1.38$ & $0.125 e \pm 0.015$ & $\begin{array}{c}3.50 \mathrm{~h} \pm \\
0.14\end{array}$ & $\begin{array}{l}0.592 \mathrm{f} \\
\pm 0.047\end{array}$ & \begin{tabular}{|c|}
25.82 \\
\pm 1.03 \\
\end{tabular} & $\begin{array}{l}0.16 \mathrm{~h} \\
\pm 0.01\end{array}$ & $\begin{array}{l}0.98 \mathrm{k} \\
\pm 0.04\end{array}$ \\
\hline & $<0.001$ & $<0.001$ & $<0.001$ & $<0.001$ & 0.81 & $<0.001$ & $<0.001$ \\
\hline
\end{tabular}

DMAR - Dry Matter Accumulation Rate

\# Data are the pooled means of three estimates each over two years \pm standard deviation. ' $p$-value' denotes the significance of difference between the means by one way ANOVA statistics. a The values followed by different letters differ significantly by Duncan's multiple range test at $\mathrm{p}=0.05$.

* Cul: Cassia uniflora Mill.non Spreng ; Snl: Synedrella nodiflora(L) Gaertn; Alt: Alternanthera tenella Colla; Eug: Euphorbia geniculata Orteg.; Ach: Achyranthes aspera L.; Bod: Boerhaavia erecta L.; Bln: Blainvillea acmella L.; Aca: Acalypha ciliata Forsk.; Tum: Triumfetta rhomboidea Jacq.; Cab: Cassia absus L.; Cfl: Cassia obtusifolia L.; Bdn: Bidens biternata Lour.; Raw: Rauwolfia tetraphylla L.; Opl: Oplismenus compositus P.Beauv.

Table 4. Photosynthetic parameters of invasive and native weeds 
Photosynthesis is the unique process that governs the plant productivity and biomass production. Hence the increased photosynthetic rate in invasive weeds might be able to increase biomass as the rate of dry matter accumulation rate resulting into higher biomass production. All these factors might be responsible for the higher dominance of selected invasive weeds in the study area. The invasive weeds studied in the present investigation like Cassia uniflora, Synedrella and Alternanthera had shown higher rate of photosynthesis, stomatal conductance, transpiration and dry matter accumulation rate over other invasive and native weeds, which might be the basic reason for the success of invasion and dominance in the campus of University of Pune (M.S.)

\subsection{Biochemical nature invasive and native weeds}

The results recorded on organic constituents like total sugars and starch indicated that Cassia uniflora had highest contents, which was followed by Synedrella, Alternanthera and Bidens. The remaining invasive and native weed species were on par for the contents of total sugars and starch, while Cassia absus, Rauwolfia and Oplismenus were at par but lower than the above mentioned weeds for starch and total sugars (Figure 2).

The invasive weeds like Cassia uniflora had shown highest contents of proteins and free amino acids, which was followed by Synedrella and Alternanthera. While Bidens, Blainvillea and Euphorbia were at par. The native weed Achyranthes had maximum contents of proteins and free amino acids, followed by Triumfetta and Boerhaavia. While remaining weed species had comparatively very less contents of proteins and free amino acids (Figure 3).

The dominant invasive and native weeds were having comparatively higher contents of reducing and total sugars, starch, proteins etc. They further explained that the superiority in organic constituents was contributing for the luxuriant growth and allelopathic potential. The chemicals released from damaged roots, root exudates and leaf leachates such as amino acids and carbohydrates may not directly act as allelopathic agents, but they can modify the activities of allelochemicals. The maximum contents of organic constituents like total sugars and starch have also indicated the better photosynthetic efficiency of these weeds over coexisting ones. The contents of primary metabolites like sugars, carbohydrates, amino acids, proteins etc. in plants also have allelopathic potential. The higher contents of all above organic constituents in Cassia and Synedrella might be responsible for their allelopathic potential.

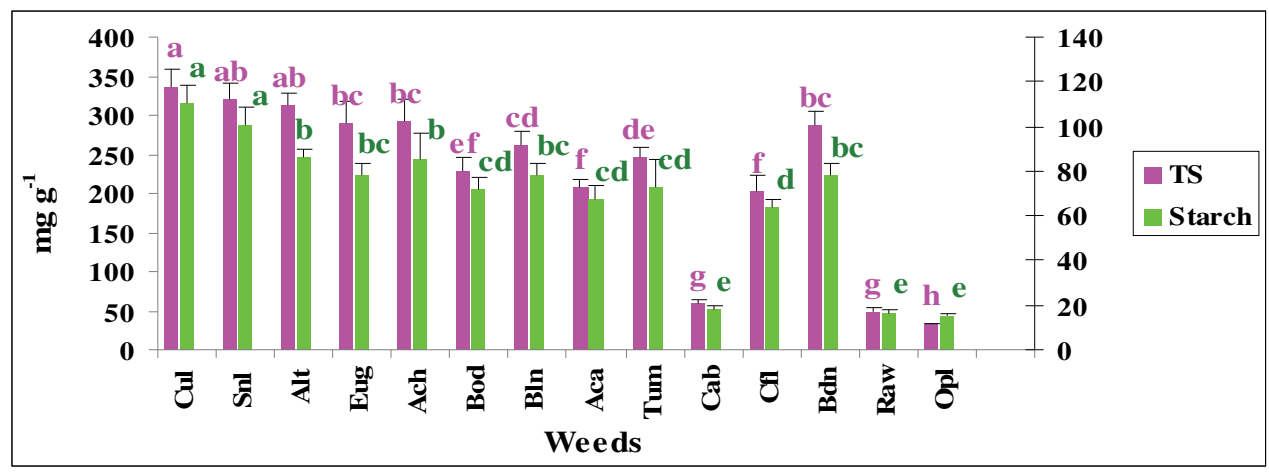

Fig. 2. Total sugars and starch contents in the invasive and native weeds 


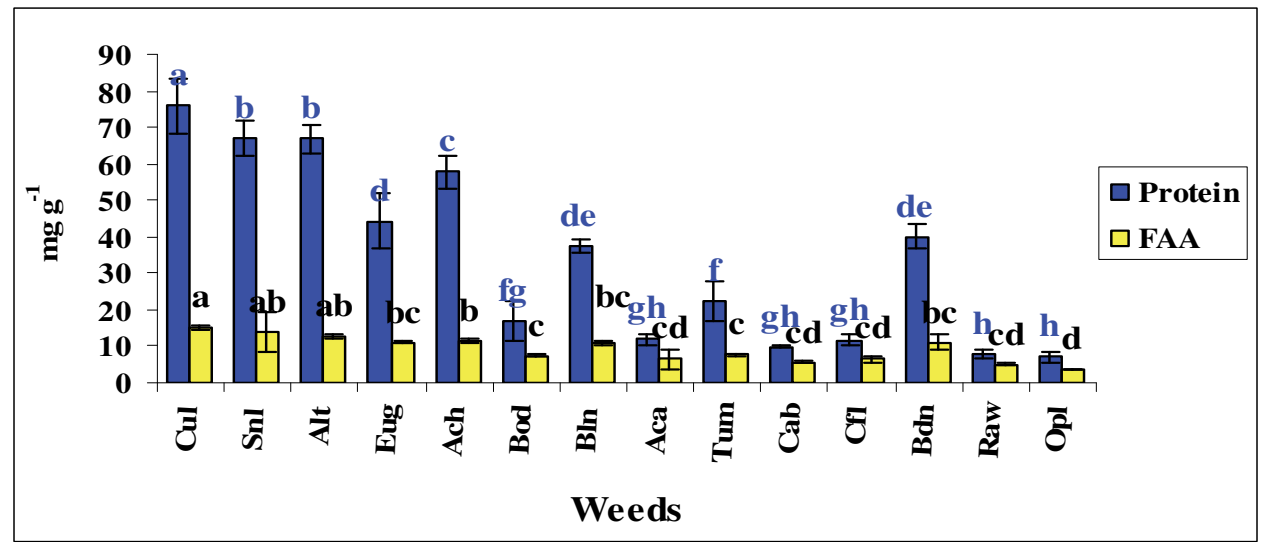

\#Data columns are the pooled means of three replicates over two years with standard deviation as error bars. a Different letters at the data points denote significant difference by Duncan's multiple range test at $\mathrm{p}<0.05$.

Fig. 3. Protein and free amino acid contentsin the invasive and native weeds

According to Blum (1996, 1997) and Inderjit and Nilsen (2003), allelopathic action can be explained by investigating the organic compounds in plants, because they may have additive effect or joint action on various biosynthetic pathways of primary and secondary metabolites. The contents of various organic constituents existing in plants may indicate their allelopathic potential, luxuriant growth and aggressive nature. Similar explanations may be applicable for the luxuriant growth and aggressive nature, faster encroachment and dominance of Cassia and Synedrella at all the four selected sites in Pune University campus, as both the weeds were highly superior in photosynthetic pigments, different photosynthetic parameters and organic constituents like sugar, starch, proteins and free amino acids.

\subsection{ROS scavenging mechanism of invasive and native weeds}

As it is well documented that invasive and native weeds have stress tolerant abilities and sustenance to withstand harsh ecological conditions due to the presence of osmolytes, antioxidants and ROS scavenging enzymes, an attempt was made for analysis of these parameters.

The results recorded in Table 5 on various antioxidants/ osmolytes/ compatible solutes like proline, glycine betaine and phenolics revealed that Cassia uniflora was having highest contents. It followed by Synedrella and Alternanthera. However the results on glycine betaine were not significant and for phenolics all the three weed species were at par.

The analysis of MDA content (lipid peroxidation) revealed that Cassia uniflora had lowest value, which was followed by Synedrella and Alternanthera. While Achyranthes was lowest amongst the native weeds.

The results on MSI showed that the index was highest in Cassia uniflora which was followed by Synedrella and Alternanthera.

The results reported in Table 5 on the relative water content of invasive and native weeds showed that here also Cassia uniflora was topmost, succeeded by Synedrella and Alternanthera. 


\begin{tabular}{|c|c|c|c|c|c|c|}
\hline $\begin{array}{l}\text { Weed } \\
\text { species }\end{array}$ & $\begin{array}{c}\text { Proline } \\
\text { m moles/g } \\
\text { DW }\end{array}$ & $\begin{array}{c}\text { Glycine } \\
\text { Betaine } \\
\mathrm{mg} / \mathrm{g}\end{array}$ & $\begin{array}{l}\text { Phenols } \\
\mathrm{mg} / \mathrm{g}\end{array}$ & $\begin{array}{c}\text { Lipid } \\
\text { Peroxidation } \\
\mathrm{T} \text { bars } \\
\end{array}$ & MSI & $\begin{array}{c}\text { RWC } \\
\%\end{array}$ \\
\hline Cul & $\begin{array}{c}38.28 \mathrm{a} \\
\pm 4.68\end{array}$ & $\begin{array}{l}0.42 \mathrm{a} \\
\pm 0.01\end{array}$ & $\begin{array}{l}8.43 \mathrm{a} \\
\pm 2.75 \\
\end{array}$ & $\begin{array}{c}0.03 \mathrm{~d} \\
\pm 1 \mathrm{E}-04 \\
\end{array}$ & $\begin{array}{c}75.64 \mathrm{a} \\
\pm 5.67 \\
\end{array}$ & $\begin{array}{l}64.8 \mathrm{a} \\
\pm 5.83 \\
\end{array}$ \\
\hline Snl & $\begin{array}{c}34.48 \mathrm{~b} \\
\pm 2.63\end{array}$ & $\begin{array}{l}0.37 \mathrm{a} \\
\pm 0.01\end{array}$ & $\begin{array}{l}8.22 \mathrm{a} \\
\pm 0.61\end{array}$ & $\begin{array}{l}0.03 \mathrm{~cd} \\
\pm 0.002\end{array}$ & $\begin{array}{c}70.11 \mathrm{ab} \\
\pm 9.93\end{array}$ & $\begin{array}{c}49.5 \mathrm{~b} \\
\pm 12.63\end{array}$ \\
\hline Alt & $\begin{array}{l}25.57 \mathrm{c} \\
\pm 1.02\end{array}$ & $\begin{array}{l}0.33 \mathrm{a} \\
\pm 0.21\end{array}$ & $\begin{array}{l}8.19 \mathrm{a} \\
\pm 0.53\end{array}$ & $\begin{array}{c}0.04 \mathrm{~d} \\
\pm 1 \mathrm{E}-04\end{array}$ & $\begin{array}{c}65.63 \mathrm{bc} \\
\pm 2.45 \\
\end{array}$ & $\begin{array}{l}41.57 \mathrm{c} \\
\pm 5.56 \\
\end{array}$ \\
\hline Eug & $\begin{array}{c}11.82 \mathrm{de} \\
\pm 0.35\end{array}$ & $\begin{array}{l}0.30 \mathrm{a} \\
\pm 0.18 \\
\end{array}$ & $\begin{array}{c}6.59 \mathrm{abc} \\
\pm 1.36\end{array}$ & $\begin{array}{l}0.04 \mathrm{~cd} \\
\pm 0.061 \\
\end{array}$ & $\begin{array}{c}60.76 \mathrm{~cd} \\
\pm 4.55 \\
\end{array}$ & $\begin{array}{c}27.9 \mathrm{de} \\
\pm 3.90\end{array}$ \\
\hline Ach & $\begin{array}{c}12.44 \mathrm{~d} \\
\pm 0.74 \\
\end{array}$ & $\begin{array}{l}0.334 \mathrm{a} \\
\pm 0.023 \\
\end{array}$ & $\begin{array}{c}7.36 \mathrm{ab} \\
\pm 0.47 \\
\end{array}$ & $\begin{array}{c}0.05 \mathrm{bcd} \\
\pm 0.002\end{array}$ & $\begin{array}{c}61.13 \mathrm{~cd} \\
\pm 3.97 \\
\end{array}$ & $\begin{array}{c}36.1 \mathrm{~cd} \\
\pm 5.05 \\
\end{array}$ \\
\hline Bod & $\begin{array}{c}6.54 \mathrm{gh} \\
\pm 0.32\end{array}$ & $\begin{array}{l}0.27 \mathrm{a} \\
\pm 0.01\end{array}$ & $\begin{array}{c}4.59 \mathrm{bcd} \\
\pm 1.38\end{array}$ & $\begin{array}{c}0.05 \mathrm{bcd} \\
\pm 0.03\end{array}$ & $\begin{array}{l}48.44 \mathrm{f} \\
\pm 2.99\end{array}$ & $\begin{array}{l}17.6 \mathrm{fg} \\
\pm 1.40\end{array}$ \\
\hline Bln & $\begin{array}{l}9.264 \mathrm{ef} \\
\pm 2.87\end{array}$ & $\begin{array}{l}0.303 \mathrm{a} \\
\pm 0.009\end{array}$ & $\begin{array}{c}6.17 \mathrm{abc} \\
\pm 2.85\end{array}$ & $\begin{array}{c}0.08 \mathrm{bcd} \\
\pm 0.08\end{array}$ & $\begin{array}{c}57.36 \mathrm{de} \\
\pm 3.15\end{array}$ & $\begin{array}{c}23.4 \mathrm{efg} \\
\pm 3.51 \\
\end{array}$ \\
\hline Aca & $\begin{array}{l}6.27 \mathrm{~h} \\
\pm 0.43 \\
\end{array}$ & $\begin{array}{l}0.26 \mathrm{a} \\
\pm 0.19 \\
\end{array}$ & $\begin{array}{l}4.06 \mathrm{~d} \\
\pm 0.38 \\
\end{array}$ & $\begin{array}{c}0.101 \mathrm{bcd} \\
\pm 0.003\end{array}$ & $\begin{array}{l}47.53 \mathrm{f} \\
\pm 4.51 \\
\end{array}$ & $\begin{array}{c}15.34 \mathrm{gh} \\
\pm 2.14 \\
\end{array}$ \\
\hline Tum & $\begin{array}{c}8.37 \text { efg } \\
\pm 0.58 \\
\end{array}$ & $\begin{array}{l}0.28 \mathrm{a} \\
\pm 0.01 \\
\end{array}$ & $\begin{array}{c}4.75 \mathrm{~cd} \\
\pm 0.26 \\
\end{array}$ & $0.1 \mathrm{bcd} \pm 0.005$ & $\begin{array}{l}50.45 \text { ef } \\
\pm 3.095 \\
\end{array}$ & $\begin{array}{c}19.65 \mathrm{efg} \\
\pm 1.37 \\
\end{array}$ \\
\hline $\mathrm{Cab}$ & $\begin{array}{c}12.41 \mathrm{~d} \\
\pm 0.21\end{array}$ & $\begin{array}{l}0.24 \mathrm{ab} \\
\pm 0.017\end{array}$ & $\begin{array}{c}5.82 \mathrm{bcd} \\
\pm 1.75\end{array}$ & $\begin{array}{c}0.103 \mathrm{bcd} \\
\pm 0.004\end{array}$ & $\begin{array}{l}45.53 \mathrm{f} \\
\pm 1.15\end{array}$ & $\begin{array}{c}15.69 \mathrm{gh} \\
\pm 0.62\end{array}$ \\
\hline $\mathrm{Cfl}$ & $\begin{array}{l}20.84 \mathrm{c} \\
\pm 0.29 \\
\end{array}$ & $\begin{array}{l}0.26 \mathrm{a} \\
\pm 0.18 \\
\end{array}$ & $\begin{array}{c}6.66 \mathrm{abc} \\
\pm 0.27\end{array}$ & $\begin{array}{l}0.13 \mathrm{bc} \\
\pm 0.008\end{array}$ & $\begin{array}{r}47.38 \mathrm{f} \\
\pm 3.554 \\
\end{array}$ & $\begin{array}{c}18.83 \text { ef } \\
\pm 2.61 \\
\end{array}$ \\
\hline Bdn & $\begin{array}{c}9.486 \text { def } \\
\pm 0.379\end{array}$ & $\begin{array}{l}0.305 \mathrm{a} \\
\pm 0.015\end{array}$ & $\begin{array}{c}6.34 \mathrm{abc} \\
\pm 2.74 \\
\end{array}$ & $\begin{array}{c}0.13 \mathrm{bc} \\
\pm 0.15\end{array}$ & $\begin{array}{c}57.94 \mathrm{de} \\
\pm 4.34 \\
\end{array}$ & $\begin{array}{l}25.9 \text { ef } \\
\pm 3.88 \\
\end{array}$ \\
\hline Raw & $\begin{array}{c}15.24 \mathrm{~cd} \\
\pm 0.31 \\
\end{array}$ & $\begin{array}{l}0.059 \mathrm{~b} \\
\pm 0.002 \\
\end{array}$ & $\begin{array}{c}5.69 \mathrm{bcd} \\
\pm 0.202 \\
\end{array}$ & $\begin{array}{r}0.17 \mathrm{~b} \\
\pm 0.007 \\
\end{array}$ & $\begin{array}{c}38.66 \mathrm{~g} \\
\pm 2.51 \\
\end{array}$ & $\begin{array}{c}15.52 \mathrm{gh} \\
\pm 0.071 \\
\end{array}$ \\
\hline Opl & $\begin{array}{c}7.54 \text { fgh } \\
\pm 0.22\end{array}$ & $\begin{array}{l}0.054 \mathrm{~b} \\
\pm 0.003\end{array}$ & $\begin{array}{c}4.41 \mathrm{~cd} \\
\pm 0.61\end{array}$ & $\begin{array}{l}0.36 \mathrm{a} \\
\pm 0.02\end{array}$ & $\begin{array}{l}34.57 \mathrm{~g} \\
\pm 2.593\end{array}$ & $\begin{array}{l}12.01 \mathrm{~h} \\
\pm 0.261\end{array}$ \\
\hline & $<0.001$ & 0.024 & $<0.001$ & $<0.001$ & $<0.001$ & $<0.001$ \\
\hline
\end{tabular}

\# Data are the pooled means of three estimates each over two years \pm standard deviation. 'p-value' denotes the significance of difference between the means by one way ANOVA statistics. a The values followed by different letters differ significantly by Duncan's multiple range test at $\mathrm{p}=0.05$.

* Cul: Cassia uniflora Mill.non Spreng ; Snl: Synedrella nodiflora(L) Gaertn; Alt: Alternanthera tenella Colla; Eug: Euphorbia geniculata Orteg.; Ach: Achyranthes aspera L.; Bod: Boerhaavia erecta L.; Bln: Blainvillea acmella L.; Aca: Acalypha ciliata Forsk.; Tum: Triumfetta rhomboidea Jacq.; Cab: Cassia absus L.; Cfl: Cassia obtusifolia L.; Bdn: Bidens biternata Lour.; Raw: Rauwolfia tetraphylla L.; Opl: Oplismenus compositus P.Beauv.

Table 5. Osmolytes and antioxidants in invasive and native weeds

The alien species like Cassia uniflora, Synedrella and Alternanthera have higher contents of different types of antioxidants as compared to the co- occurring invasive and native weeds at the selected sites of Pune University campus (Table 5). Along with this lower values of lipid peroxidation and higher MSI and RWC might be offering them additional mechanisms for abiotic stress tolerance. As a result of this the selected invasive weeds might have succeeded to invade and encroach over the native plants of Pune University campus even during the harsh environmental conditions. 
The enhancement in various antioxidants was reported by many allelopathy workers like Tambussi et al. (2000), Horling et al. (2003), Guha et al. (2004), Yang and Lu (2005) in different types of invasive plants growing in terrestrial and boreal forest communities of North America. The role(s) of different antioxidants and osmolytes existing in the invasive and native weeds of forest and cropland ecosystems are very much important. They have explained that the antioxidants were helpful for these weeds to become dominant over cooccuring plant species.

The free radicals are constantly generated under stress conditions which are quenched by an efficient antioxidant network in the plant body. The complex network of such adaptive mechanisms at physiological and molecular levels cause changes in the synthesis and accumulation of various osmolytes, antioxidants and antioxidant enzymes, which provide stress tolerance to the plants (Bagul et al. 2005, Bhattacharya et al. 2009).

Proline is a major organic osmolyte accumulating in a variety of plant species in response to biotic and abiotic stresses, though its actual role in plant osmo-tolerance remains controversial. It is also thought to help in stabilization of sub-cellular structures (e.g. membranes and proteins), and to scavenge free radicals under stress conditions. Proline is known to occur widely in higher plants and normally accumulates in large quantities in response to environmental stresses (Kavi Kishore et al. 2005).

The rapid breakdown of proline upon relief of stress may provide sufficient reducing agents that support mitochondrial oxidative phosphorylation and generation of ATP for recovery from stress and repairing of stress induced damages (Zhu 2002). In response to drought or salinity stress in plants proline also helps for cytoplasmic osmotic adjustment. Accumulation of proline under stress in many plant species has been correlated with stress tolerance, and its concentration has been shown to be generally higher in stress - tolerant than in stress - sensitive plants (Ashraf and Harris 2004, Ashraf and Foolad 2007). Comparatively higher amount of proline accumulation in Cassia and Synedrella might be functioning as mentioned above providing stress tolerance to these weeds, as a result of which both the weeds were able to survive throughout the year and producing large no. of seeds even under unfavourable stress conditions. These outnumbering seeds of both the invasive weeds when germinate during favourable season, naturally establish the monothickets or pure stands which caused substitution of many natives resulting into loss of phytodiversity of Pune University campus.

Malondialdehyde (MDA) is a product of lipid peroxidation by a thiobarbituric acid reaction. During drought conditions high activities of antioxidant enzymes are associated with lower concentration of MDA, being linked to drought tolerance (Gao et al. 2008). Like proline lowest values of MDA in Cassia and Synedrella can be linked with drought tolerance and better survival in extremely adverse environmental conditions.

One of the most common responses in plants to abiotic stresses is overproduction of different types of compatible organic solutes (Serraj and Sinclair 2002), which protect the plants from stress injuries by cellular osmotic adjustment, detoxification of ROS, protection of membrane integrity and stabilization of enzymes/ proteins. The antioxidants also protect cellular components from dehydration injury. These solutes include proline, sucrose, polyols, trehalose and quaternary ammonium compounds (QACs) such as glycine-betaine, alanine-betaine, proline-betaine, choline $O$-sulfate, hydroxyproline-betaine and pipecolatebetaine (Rhodes and Hanson 1993). 
Amongst the many quaternary ammonium compounds known in plants, glycine betaine occurs most abundantly in response to dehydration stress (Venkatesan and Chellappan 1998, Mansour 2000). GB is abundant mainly in chloroplast where it plays a vital role in adjustment and protection of thylakoid membrane, thereby maintaining photosynthetic efficiency. The results of present investigation on antioxidants indicated more accumulation of GB in Cassia and Synedrella as compared to the native weeds at selected sites of Pune University campus. Along with high proline and low MDA, GB might also be contributing for stress tolerance and thereby maintaining the photosynthetic efficiency of both the dominant invasive weeds as suggested by Genard et al. (1991).

RWC has special significance in physiological activities of plants. The results of the present investigation indicated that Cassia and Synedrella had significantly higher RWC as compared to other invasive and native weeds. It may be the additional physiological adaptation for drought tolerance along with above mentioned antioxidants.

Likewise MSI decides the extent of membrane perturbations in structure and dysfunctioning in the cellular activities during the stress conditions. The membrane stability index (MSI) is very important parameter that gives idea about the stress tolerance ability of invasive and native weeds. The MSI of weeds under investigations agree with this. Increase in allelochemicals in these weeds might also be helping the weeds to get more stress tolerance. Membranes are barriers isolating aqueous compartments of the cells and the membrane proteins participate in signal reception and in transport of specific solutes giving them stability and thereby afford stress tolerance to the plants (Ramadevi et al. 1997). The higher values of MSI in both the invasive weeds recorded in the present investigation may be having similar role as mentioned above, because of which these weeds are tolerating extreme environmental conditions, survive comfortably and invade successfully in the new habitats. On the contrary the native weeds are not able to tolerate the stress conditions and hence make the place for highly tolerant invasive weeds. This results in to loss of native phytodiversity in that particular ecosystem.

\subsection{Antioxidant enzymes in invasive and native weeds}

The activities of antioxidant enzymes like PPO (Polyphenol oxidase), POX (Peroxidase) and SOD (Superoxide dismutase) (Figure 4,5), were stimulated in Cassia uniflora followed by Synedrella and Alternanthera. The remaining invasive and native weeds followed the above mentioned weed species. The difference in stimulation of these enzymes might be due to the difference in stress tolerance ability of these weeds. More accumulation of antioxidants and stimulated activities of antioxidant enzymes might be becoming helpful for stress tolerance to these weeds. The results of the present investigations are in agreement with the findings of Bhalerao (2003), Jadhav (2006), Vaidya (2009) and Ghayal et al. (2009). They have also reported comparatively higher stimulation of antioxidant enzymes like PPO, POX and SOD in some invasive as well as native weeds of forest, aquatic and terrestrial ecosystems. They further concluded that more accumulation of antioxidants and stimulated activities of antioxidant enzymes were helpful for stress tolerance to these weeds.

Antioxidative enzymes, such as superoxide dismutase (SOD), peroxidases (POD) and polyphenol oxidase (PPO), are the most important components in the ROS scavenging system. SOD dismutates $\mathrm{O}_{2}{ }^{-}$to $\mathrm{H}_{2} \mathrm{O}_{2}$, POD and PPO subsequently scavenge the $\mathrm{H}_{2} \mathrm{O}_{2}$. The activities of antioxidant enzymes are usually stimulated on exposure to oxidative stress, for protecting the plants, because these enzymes scavenge the reactive oxygen species (Tanaka 1994). The invasive and native weeds studied in the present investigation had shown very 
high stimulation in the activities of above mentioned enzymes in response to stress conditions, which might be responsible for survival of these weeds in extreme ecological conditions existing in the campus of Pune University. Ping Lu et al. (2007) supported the above view.

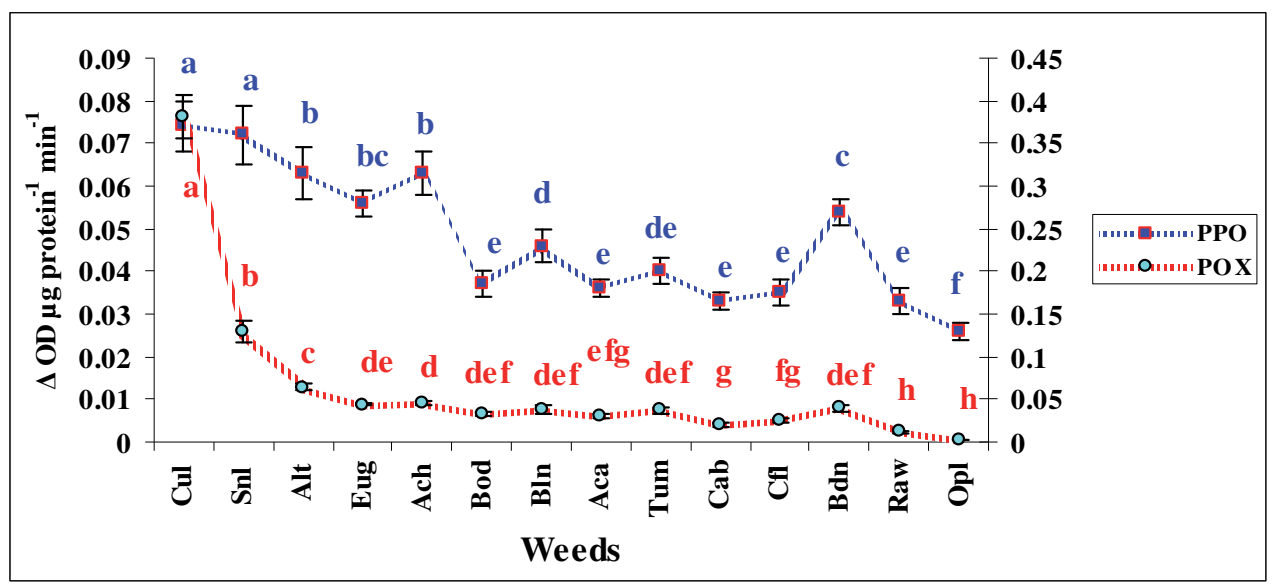

Fig. 4. Activity of polyphenol oxidase and peroxidase in the invasive and native weeds

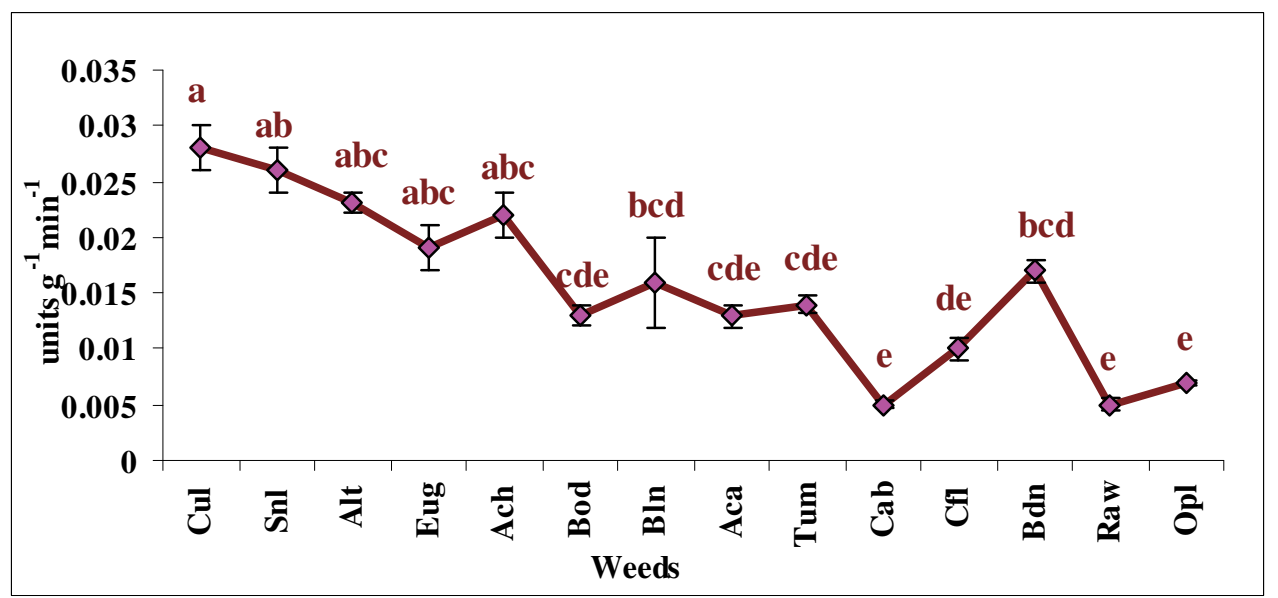

\#Data points are the pooled means of three replicates over two years with standard deviation as error bars. a Different letters at the data points denote significant difference by Duncan's multiple range test at $\mathrm{p}<0.05$.

Fig. 5. Activity of superoxide dismutase in the invasive and native weeds 


\section{Allelobiogenesis of invasive weeds}

To understand the allelopathic nature of any plant, extraction, identification and characterization of allelochemicals in its roots, stems and leaves has predominant role. In fact, all the interpretations in allelopathy are mostly based on such investigations. However, collection, isolation and complete identification, characterization and quantification of allelochemicals is difficult and a challenge to the allelopathy scientists. The allelochemicals like terpenes, steroids, flavonoids, alkaloids etc. have major impact on physiology of recipient plants, right from gene to organism level e.g. the monoterpenes which are the main constituents of the essential oils from many higher plants, interfere with basic biological processes like DNA replication, respiration, enzyme activities, seed germination and plant growth. These monoterpenes have allelopathic action. Triterpenes from many different weeds like Cassia, Lantana, Mikania are known for their allelopathic responses and great ecological significance with respect to invasion Ghayal et al. (2007a).

The allelochemicals like terpenoids, steroids, phenols and bitter essential oils present in roots, stems and leaves of Cassia and Synedrella might be released in to their environment, through various processes in the form of extracts, leachates, root exudates and even residues of all above plant parts which in due course of time become allelopathic to associated invasive and native weeds as a result of which they were suppressed slowly and substituted by Cassia and Synedrella. This phenomenon was observed at all the four sites of Pune University campus.

\subsection{GC-MS study}

The phytosociological dominance of Cassia uniflora and Synedrella nodiflora at the four selected sites in Pune University campus recorded previously and the inhibitory weed-weed interaction between these invasive weeds and co-occuring native weeds can be attributed to the different types of allelochemicals existing in them which are detected with GC-MS. The allelopathic potential exhibited by both the weeds might be due to different types of allelochemicals existing in them.

The distribution, quantity and type of allelochemicals depends on various factors such as age of the plant, growing season, vegetative or reproductive phase, environmental conditions and habitat. The allelopathic influence of extracts, leachates or residues of such plants is due to the different types of allelochemicals such as salts, esters, fatty acids, alkaloids, glycosides, terpenoids, flavonoids and steroids present in them. Their solubility in different solvents and mechanism of actions of such allelochemicals mostly depend on their chemical nature. These allelochemicals might be exuded, excreted or released from the plants. The chemical nature of such allelopathic compounds governs the process of invasion, dominance, distribution and encroachment over co-occurring species in any ecosystem.

Many researchers have isolated more than ten thousand low molecular weight secondary metabolites from higher plants and fungi. These compounds or their analogs are new sources of allelochemicals. Drager (2002), Mashhadi and Rodosevich (2003), Bhalerao (2003), Haig (2004), Elzaawely et al. (2005), and Alonso-Amelot (2006) had detected different types of allelochemicals from various weeds and fern species with GC-MS technique and studied their allelopathic activity. Ru Bai et al. (2009) also reported many allelopathic compounds by GC-MS in root exudates of Malus prunifolia. Qiaoying Zhang et al. (2009) detected allelopathic potential of flowers and fruits of Lantana camara which was ascribed to the allelochemicals by GC-MS. Seal et al. (2009) had also identified different allelochemicals 
in weed species like Shepherd's purse (Capsella bursa-pastoris) by GC-MS and studied its phytotoxicity.

\subsection{IR, NMR, and MASS spectra studies}

The dominance, negative weed-weed interaction, encroachment over native weeds as well as successful invasion of Cassia uniflora and Synedrella recorded at all the four selected sites in the campus of Pune University can be attributed to the existence of different types of allelochemicals in the leaves of both the weeds such as $2(4 \mathrm{H})$ - Benzofuranone,5,6,7,7atetrahydro-4,4,7a-trimethyl (Dihydroactinidiolide), 2-pentadecanone, Isobutyl phthalate, 4,4,8-trimethyltricyclo [6.3.1.0(1,5)]dodecane-2,9-diol, Hexadecanoic acid, Phytol, Dioctyl phthalate, Neophytidiene, Caryophylene oxide and Di-isooctyl phthalate. The presence of above allelochemicals in both the invasive weeds was well documented by Ghayal et al. (2007). The presence of allelochemicals such as Dodecane-4- yl butyrate in Cassia leaves and 3-(5-(1-(3-methylpentyloxy) propyl)-tetrahydro-2-oxofuran-3-yl)-dihydrofuran-2(3H)-one in Synedrella leaves were detected for the first time in the present investigation.

Many allelopathy researchers such as An et al. (2000), Orr et al. (2005) and Santos et al. (2007) separated, identified and quantified the allelochemicals from different weeds and tested their phytotoxicity. Yang et al. (2006) also have separated and identified allelochemicals by NMR in Ageratina adenophora and studied their allelopathic activity on rice seedlings. Isolation and bioactivity of withaferin A from Withania somnifera roots was done by Kannan and Kulandaivelu (2007). Leicach et al. $(2007,2009)$ have used different methods of chromatography and spectroscopy for alkaloid separation and identification from different plants and elaborately discussed the importance of extraction, separation and identification of allelochemicals from different plants having allelopathic activity. Ma et al. (2009) and Li et al. (2009) have attempted the isolation and identification of allelochemicals by NMR and Mass in invasive plants Ipomoea cairica and Polygonatum odoratum respectively.

The results of the present investigation are in conformity with the above findings.These allelochemicals usually had greater adverse impact on the physiological as well as biochemical processes, enzymological activities, nutrient uptake and assimilation, reproductive abilities, growth and development of recipient plant species. The changes induced by allelochemicals at molecular level are also expressed in phenotypes. The antimicrobial activity in leaf leachates and extracts of Cassia and Synedrella might be due to the presence of allelochemicals such as terpenoids, steroids, flavonoids, pungent and bitter essential oils and various types of phenols present in them.

\section{Conclusions}

The present investigations attempted on phytosociology, physiology, biochemistry and enzymology of selected weeds, phytochemicals and allelochemicals existing in them, their allelopathic potential tested through seed germination bioassays, seedling growth and physiological, biochemical and enzymological changes including treated seedlings of testcrops due to leachates of selected invasive weeds, clearly revealed that the basis for all such events was allelopathic nature of Cassia and Synedrella.

The weed - crop interactions at molecular, cellular and whole plant level were also attempted with special emphasis, as these weeds in future are likely to invade agroecosystems and croplands. At present slowly they are spreading from wastelands to agricultural lands and competing with the crops of interest and cause significant yield loss. 
The studies on impact of leachates, extracts and even residues of Cassia and Synedrella revealed that higher concentrations had severe and very dreadful influence on physiology, biochemistry and enzymology of test crops and such negative changes were also manifested on growth and yield attributes of crops interacting with weeds.

These investigations have also thrown a light on successful invasion of both the weeds in the campus of Pune University, their dominance, aggressiveness and encroachement over native and even other invasive weeds. The ecological and morphological superiority enabled them to do so very efficiently and effectively. The exclusive dominant nature of selected invasive weeds and their allelopathic potential resulted into the loss of native phytodiversity, which is the major threat of such invasion to any ecosystem. Such investigations may become the basis for exploring environmental and ecological degradations in nature.

\section{Future research}

The need for research and development in allelopathy for the improvement of agriculture, forestry and different types of ecosystems, community structures and functioning is of extreme urgency, because the understanding of allelopathy has major role(s) in the interactions between invasive/ exotic and native weeds, weeds-crops, crops-crops etc. These studies are of utmost importance in agriculture, forestry and environmental degradation. Many of these weeds cause damages to agroecosystems and disturb natural phytodiversity. Their dominance, luxuriant growth, persistence throughout the year, tolerance to biotic and abiotic stress conditions and allelopathic potential might be the probable factors of successful invasion in new habitats.

The use of naturally produced huge weed biomass for weedicidal, cytotoxic, larvicidal, insecticidal and antimicrobial activity is gaining ground in sustainable agriculture. With this view many research workers have reported the antimicrobial activity in different plant parts and extracts, leachates or residues of large number of plant species available in plenty.

The richness of bioactive compounds, secondary metabolites and variety of allelochemicals present in these weeds and other co-dominant weeds can give enticement to screen their cytotoxic, genotoxic, larvicidal, antimicrobial activities etc. The results of such experiments could be positive, if the analyses of their bioactive compounds, antioxidants and antioxidant enzymes is given due importance. The studies on genomics and proteomics of different weeds, having biotic and abiotic stress tolerance can be exploited with the aid of biotechnological tools, to have such type of agronomic traits in various crops. Only the coupling of all the aspects of studies can give an applied touch to the entire field of allelopathy.

\section{References}

Aldrich, R.J. (1984). Weed - crop ecology: Principles in weed management. Breton Pub., N. Scituate, MA. pp. 5 - 6.

Alonso-Amelot, M.E., Usubillaga, A., Avila-Nunez, J.L., Oliveros-Bastidas, A. and Avendano, M. (2006). Effects of Minthostachys mollis essential oil and volatiles on seedlings of lettuce, tomato, cucumber and Bidens pilosa. Allelopathy Journal 18(2): $267-276$. 
An, M., Haig, T. and Pratley, J. E., (2000). Phytotoxicity of Vulpia : II Separation, identification and quantification of the allelochemicals from Vulpia myuros. J. Chem. Ecol. 26: 1465 - 1476.

Ashraf, M. and Harris, P. J. (2004). Potential biochemical indicators of salinity tolerance in plants. Plant Sci. 166: 3 - 16.

Ashraf, M. and Foolad, M.R. (2007). Roles of glycine betaine and proline in improving plant abiotic stress resistance. Environ. Exp. Bot. 59: 206 - 216. DOI: 10.1016/j.envexpbot. 2005.12.006

Azania, A.A.P.M., Azina, C.A.M., Alves, P.L.C.A., Palaniraj, R., Kadian, H.S., Sati, S.C., Rawat, L.S, Dahiya, D.S. and Narwal, S.S. (2003). Allelopathic plants 7. sunflower (Helianthus annus L.). Allelopathy Journal 11(1): 1 - 20.

Bagul, M.S., Kanaki, S.N. and Rajani, M. (2005). Evaluation of free radical scavenging properties of two classical polyhedral formulations. Ind. J. Exp. Biol. 43: 732 - 736.

Baker, H. G. (1965). Charactristics and modes of origin of weeds. Pp. 147 - 172, in Genetics of colonizing species. Proc. First Int. Union of Biological Sci. Symp. On Gen. Biol. H. G. Baker and G. L. Stebbins, ed. Academic Press, New York.

Bartariya, G., Saxena, A., Srivastva, J. N., and Satsangi, G. P. (2005). Allelopathic potential of Cyperus rotundus L. on germination and seedling growth of Oryza sativa L. Allelopathy Journal. 16(2): 353-358.

Batish, D.R., Singh, H.P., Pandher, J.K., Arora, V. and Kohli, R.K. (2002). Phytotoxic effect of Parthenium residues on the selected soil properties and growth of chickpea and radish. Weed Biol. Management 2: 73-78.

Bhakat, R.K., Bhattacharjee, A., Maiti, P.P., Das, R.K. and Kanp, U.K. (2006). Effect of Eupatorium odoratum L. on Mimosa pudica L. Allelopathy Journal 17(1): 113 - 116.

Bhalerao, E.B., Laware, S.L., Vaidya, R.R.and Dhumal, K.N. (2000a). Influence of leaf leachates of Pteridium and Aspidium on physiology of Mentha. J. Med. Arom. Plant Sci., 22/4A \& 23/1A: 502-504.

Bhalerao, E.B., Laware, S.L., Vaidya, R.R.and Dhumal, K.N. (2000b). Effect of Aspidium cicutarium rhizome extracts on seed germination and seedling growth of jowar and bajra. J. Med. Arom. Plant Sci., 22 (4A) and 23(1A): 499-501.

Bhalerao, E. B. (2003). Physiological studies in some crop plants with reference to application of fern frond extracts, Ph.D thesis, Department of Botany University of Pune.

Bhan, V.M., D.B. Bhaskar Choudhary (1976). Germination, growth and reproductive behaviour of Phalaris minor Retz. As affected by date of planting. Ind. J. Weed Sci. 18: $126-130$.

Bhatt, B.P. and Chauhan, D.S. (2000). Allelopathic effects of Quercus spp. on crops of Garlwal Himalaya. Allelopathy Journal 7: 265-273.

Bhattacharya Malay, Mandal Palash and Sen Arnab (2009). In vitro detection of antioxidants in different solvent fractions of Ginger (Zingiber officinale Rosc.). Ind. J. Plt. Physiol. 14(1) N.S.: $23-27$.

Blicker P.S., B.E. Olson and J.M. Wraith (2003). Water use and water-use efficiency of the invasive Centaurea maculosa and three native grasses. Plant and Soil. 254: 371-381.

Blum, U. (1996). Allelopathic interactions involving phenolic acids. J. Nematol., 28(3): 259267. 
Blum, U. (1997). Benefits of citrate over EDTA for extracting phenolic acids from soils and plant debris. J. Chem. Ecol., 223: 347- 362.

Callaway, R.M., Ridenour, E.T. (2004). Novel weapons: invasive success and the evolution of increased competitive ability. Front Ecol Environ. 2: 436 - 443.

Carballeira, A. and Reigosa, M.J. (1999). Effects of natural leachates of Acacia dealbata link in Galicia (NW Spain). Bot. Bull. Acad. Sin., 40: 87-92.

Carlton, J. T. (2001). Introduced species in U.S. Coastal Waters: Pew Oceans Commissions Report. Pew Oceans Commissions: Washington, DC.

Carpenter, D., Cappuccino, N. (2005). Herbivory, time since introduction and the invasiveness of exotic plants. J Ecol. 93: 315 - 321.

Castillo Jesu’ s M., Pablo Leira-Doce, Jorge Carrio’ n-Tacuri, Edison Mun oz-Guacho, Aı́da Arroyo-Solı's, Guillermo Curado, David Doblas, Alfredo E. Rubio-Casal, Antonio A. A' lvarez-Lo' pez, Susana Redondo-Go'mez, Regina Berjano, Giovanny Guerrero, Alfonso De Cires, Enrique Figueroa, Alan Tye. (2007). Contrasting strategies to cope with drought by invasive and endemic species of Lantana in Galapagos. Biodivers Conserv. 16: 2123-2136.

Chapin, F.S. III, Zavaleta, E.S., Eviner, V.T., Naylor, R.L., Vitousek, P.M., Reynolds, H.L., Hooper, D.U., Lavorel, S., Sala, O.E., Hobbie, S.E., Mack, M.C. and Diaz, S. (2000). Consequences of changing biodiversity. Nature 405: 234-242.

Chase, J.M. and Leibold, M.A. (2003). Ecological niches. The Univesity of Chicago Press, Chicago.

Cheema, Z.A., Iqbal, M.and Ahmad R., (2002) Response of wheat varieties and some winter weeds to allelopathic effects of sorghum water extract. Int. J. Agri. Biol. $\quad$ 4: 52 55.

Chon, S.U., Kim,Y.M. Lee, J.C. (2003). Herbicidal potential and quantifications of causative allelochemicals from compositae weeds. Weed Research 43: $444-450$.

Chou, C. H. (1999). Roles of allelopathy in plant biodiversity and sustainable agriculture. Critical reviews in Plant Sciences. 18: 609 - 636.

Colautti, R.I. and MacIsaac, H.J. (2004). A neutral terminology to define 'invasive' species. Diversity and Distributions 10: $134-141$.

Daehler, C.C. (2003). Performance comparisons of co-occurring native and alien invasive plants: implications for conservation and restoration. Ann. Rev. Ecol. Evol. Systematics. 34: 183 - 211.

Davis, M.A., Grime J.P., Thompson, K. (2000). Fluctuating resources in plant communities: a general theory of invisibility. J. Ecol. 88: $528-534$.

Dekker, J. (2005). Biology and anthropology of plant invasions. In: Invasive Plants: Ecological and agricultural aspects (Ed. Inderjit) pp. 235 - 250. Birkhauser Verlag / Switzerland.

Devi, S.R., Pellissier, F. and Prasad, M.N.V. (1997). Allelochemicals. In: Plant Ecophysiology (Ed. M.N.V. Prasad, pub. John Wieley, New York). pp 253-303.

DeWalt, S.J., Denslow, J.S., Hamrick, J.L. (2004) Biomass allocation, growth, and photosynthesis of genotypes from native and introduced ranges of the tropical shrub Clidemia hirta. Oecologia 138: 521-531.

Drager, B. (2002). Analysis of tropane and related alkaloids. J Chromato. A. 978: 1 - 35.

Durand, L.A., Goldstein, G. (2001). Photosynthesis, photoinhibition, and nitrogen use efficiency in native and invasive tree ferns in Hawaii. - Oecologia 126: 345-354. 
Ehrenfeld, J.G. (2003). Effects of exotic plant invasions on soil nutrient cycling processes. Ecosystems 6: 503 - 523.

Einhellig, F.A. (1987). Interactions among allelochemicals and other stress factors of the plant environment. Am. Chem. Soc. Symp. Ser. 330: 343-357.

Elton, C.S. (1958). The ecology of invasions by animals and plants. Methuen, London, UK.

Elzaawely, A.A., Xuan T.D. and Tawata S. (2005). Allelopathic activity and identification of allelochemicals from Rumex japonicas Houtt. Allelopathy Journal 16(2): 209 - 216.

Endress, B.A. and Parks, C.G. (2004). Element Potentilla recta. Vol. 2004. The Nature Conservancy, Arlington, VA.

Ewe, S.M.L., Sternberg, L.S.L. (2003) Seasonal exchange characteristics of Schinus terebinthifolius in a native and disturbed upland community in Everglade National Park, Florida. Forest Ecol. Manag. 179: 27-36.

Friedman, J. and Waller, G.R. (1983). Seeds as allelopathic agents. J Chem Ecol. 9: 1107 1117.

Fujii, Y., Hirdate S. and Hrya, H. (2002). In: Abstr. $3^{\text {rd }}$ World cong. on Allelopathy Challenge for the new millennium Ed.: Tsukuba, Japan.

Funk J.L. and Vitousek P.M. (2007). Resource use efficiency and plant invasion in low resource systems. Nature. 446: 1079 - 1081.

Gao Jianming, Qiang Xiao, Liping Ding, Mingjie Chen, Liang Yin, Jinzhi Li, Shiyi Zhou, Guangyuan He. (2008). Differential responses of lipid peroxidation and antioxidants in Alternanthera philoxeroides and Oryza sativa subjected to drought stress. Plant Growth Regul. 56: 89-95. DOI 10.1007/s10725-008-9291-6.

Genard, H., Le Saos, J., Hillard, J., Tremolieres, A., Boucand, J. (1991). Effect of salinity on lipid composition, glycine betaine content and photosynthetic activity in chloroplasts of Snaeda maritime. Plant Physiol. Biochem. 29: 421 - 427.

Ghayal, N.A., Dhumal, K.N., Deshpande, N.R., Kulkarni, A.M., Phadke, A.U. and Shah, S.M. (2007a). Phytotoxic effects of Cassia uniflora leaf leachates on gerrminartion and seedling growth of radish (Raphanus sativus) and mustard (Brassica juncea) Allelopathy Journal 19(2): 361-372.

Ghayal N.A., Dhumal K.N., Deshpande N.R., Shah, S.M. and Ruikar A.D. (2007b). Studies on Allelochemicals in Synedrella nodiflora and Impact of its Leaf Leachates on Germination and Seedling growth of Radish (Raphanus sativus) and Mustard (Brassica juncea) - Asian Journal of Chemistry 20 (8): 6114 - 6120.

Ghayal N.A., Dhumal, K.N., Deshpande, N.R., Shah, S.M. and Tambe, A. (2007c). Steam Volatile Components from Cassia uniflora and Synedrella nodiflora by Gas Liquid Chromatography - Mass Spectroscopy - Journal of Indian Council of Chemists 24(2): $60-62$.

Ghayal, N. A., Dhumal, K. N., Gupta, S. G., Parange S. and Phadke M. (2009). Mophophysiological studies in some invasive weeds from deccan pleateau. Journal of Plant interactions. 4(1): 33 - 39. DOI- 10.1080 / 17429140802385964

Gill, D.S. and Sandhu, K.S. (1996). Growth stages of sunflower (Helianthus annus L.) in relation to allelopathic effects on pearlmillet. Indian J. Ecol. 23: 54 -56.

Guha, P., Mukhopadhyay, R., Pal, P.K. and Gupta, K. (2004). Antimicrobial activity of crude extracts and extracted phenols from gametophytic and sporophytic plant parts of Adiantum capillus- veneris L. Allelopathy Journal 13(1): 57-66. 
Haig, T. (2004). Allelopathy, Chemistry and mode of action of allelochemicals. Ed. Macias, F.A., Galindo, J.C.G., Molinillo, J.M.G., Cutler, H.G. pp. 149 - 160.CRC Press. London.

Hase, C.P. (2008). Allelopathic and physiological studies in sugarcane under monoculturing from different recovery zones of Maharashtra. Ph.D. thesis - University of Pune.

Hierro and Callaway R. (2003). Allelopathy and exotic plant invasion, Plant and soil. 256: 1, 29-39.

Horling, F., Lamkemeyer, P., Konnig, J., Finkemeir, I., Kandlbinder, A., Baier, M. (2003). Divergent light-, ascorbate-, and oxidative stress-dependent regulation of expression of the peroxiredoxin gene family in Aarabidopsis. Plant Physiol. 131: 317-325. DOI: 10.1104/pp. 010017.

$\mathrm{Hu}$, Y.J. and Wang, Y.F. (2001). A study on the vegetation and reproduction of two weedy herbaceous vines. Acta Scientiarum Naturalium Universitatis Sunyatsen. 40: 93 - 96.

Huang Hua, Guo Shuiliang, Chen Guoqi (2007). Reproductive biology in an invasive plant Solidago canadensis. Front. Biol.China. 2(2): 196-204. DOI 10.1007/s11515-007-0030-6.

Inderjit and Nilsen, E.T. (2003). Bioassays and field studies for allelopathy in terrestrial plants: Progress and problems. Crit. Rev. Plant Sci., 22: 1-18.

Inderjit, Marc W. Cadotte and Robert I. Colautti (2005a). The ecology of biological invasions: past, present and future. In: Invasive Plants: Ecological and agricultural aspects (Ed. Inderjit) pp. 19 - 44. Birkhauser Verlag / Switzerland.

Inderjit, Weston, L.A. and Duke, S.O. (2005b). Challenges, achievements and opportunities in allelopathy research. J. Plant Interactions, 1(2): 69-81.

Jadhav, S.S. (2006). Allelopathic potential of some dominant aquativ weeds of Mula and Mutha River and their bioprospecting. Ph.D. Thesis, University of Pune.

Jeschke, J.M. and Strayer, D.L. (2005). Invasion success of vertebrates in Europe and North America. Proceedings of the National Academy of Sciences. 102(20): 7198 - 7202.

Kanchan, S.D. and Jayachandra (1977). Parthenium weed menace in India and its control. Weed Sci. Conf. workshop in India. Abstract No. 162.

Kannan, N.D. and Kulandaivelu, G. (2007). Novel method to isolate Withaferin A from Withania somnifera roots and its bioactivity. Allelopathy Journal 20(1): 213 - 220.

Kavi Kishore, P.B., Sangam, S., Amrutha, R. N., Laxmi, P.S., Naidu, K.R., Rao, K.R.S.S., Rao, S., Reddy K.J., Theriappan, P., Sreenivasulu, N. (2005). Regulation of proline biosynthesis, degradation, uptake and transport in higher plants: its implications in plant growth and abiotic stress tolerance. Curr. Sci. 88: $424-438$.

Khanh, T.D., Cong, L.C., Xuan, T.D., Uezato, Y. Deba, F., Toyama, T. and Tawata, S. (2009). Allelopathic Plants: 20. Hairy Beggarticks (Bidens pilosa L.) Allelopathy Journal 24(2): $243-254$.

Kong, C.H. and Hu, F. (2001). Plant Allelopathy and its application. Pp. 169 - 201. Chinese Agricultural Press, Beijing, China.

Kulvinder, K., Kapoor, K.K. and Kaur, K. (1999). Effect of incorporation of sunflower residues in soil on germination of mung bean and pearlmillet. Environ. and Ecol., 17: 693-695.

Kumar, M., Sharma, C.M. and Rajwar, G.S. (2004). A study on community structure and diversity of a sub-tropical forest of Garhwal Himalayas. Indian Forester 130(2): 207 214.

Leather, G.R. and Einhellig, F.A. (2005). Bioassay of naturally occurring allelochemicals for phytotoxicity. J. Chem. Ecol., 14(10): 1821-1828. 
Lee, K.A. and Klasing, K.C. (2004). A role for immunology in invasion biology. Trends in Ecology and Evolution. 19: 523-529.

Leicach, S.R., Chludil, H. and Yaber Grass (2007). Chromatographic and spectroscopic techniques applied to alkaloid separation and identification. In: Isolation, identification and characterization of allelochemicals/ Natural products (Eds. S.S. Narwal, D.A. Sampietro, C.A.N. Catalan and M.A. Vattuone) USA: Science Publishers. (In press).

Leicach, S.R., Sampietro, D.A. and Narwal, S.S. (2009). Separation and identification of allelochemicals. In: Allelochemicals: Role in Plant - Environmental Interactions. pp. 149 162. Studium Press, LLC, Texas, USA.

Li, D.W., Wang, D.M., Li, J.L. and Chen, C. (2009). Allelopathic effects of Polygonatum odoratum rhizome extracts and its isolated allelochemicals. Allelopathy Journal 23(1): $119-128$.

Lin, S.Z., Du, L. and Cao, G.Q. (2002). Advance and application prospects on allelopathy research in forestry. J. Fujian College Fores., 22: 184-188.

Lonsdale, W. M. (1999). Global patterns of plant invasions and the concept of invasibility. Ecology 80: 1522 - 1536.

Ma, R.J., Wang, N.L., Zhu, H., Guo, S.J. and Chen, D.S. (2009). Isolation and identification of allelochemicals from invasive plant Ipomoea cairica. Allelopathy Journal 24(1): 77 - 84.

MacDougall, A.S., Turkington, R. (2005). Are invasive species the drivers or passengers of change in degraded ecosystems? Ecology. 86: 42 - 55.

Mack, R. N., Simberloff, D., Lonsdale, W. M., Evans, H., Clout, M. and Bazzaz, F. A. (2000). Biotic invasions: Causes, epidemiology, global consequences and control. Ecol. Appl. 10: 689-710.

Mansour, M. M. F. (2000). Nitrogen containing compounds and adaptation of plants to salinity stress. Biol. Plant. 43: $491-500$.

Maron, J.L. and Vila, M. (2001). When do herbivores affect plant invasion?Evidence for the natural enemies and biotic resistance hypothesis. Oikos 95: 361 - 373.

Mashhadi, H.R. and Steve R. Rodosevich (2003). Weed Biology and Management (Ed. Inderjit). Pp. 1 - 28. Kluwer Academic Publishers.

McDowell, S.C.L. (2002). Photosynthetic characteristics of invasive and noninvasive species of Rubus (Rosaceae). - Amer. J. Bot. 89: 1431-1438.

Meekins, J.F. and McCarthy, B.C. (2001). Effect of environmental variations on the invasive success of a nonindegenous forest herb. Ecolog Applic. 11:1136 - 1348.

Millenium Ecosystem Assessment (2005). Ecosystems and human well-being: Synthesis. Island Press, Washington, DC, USA.

Mishra, D., Mishra, T.K. and Banerjee, S.K. (1997). Comparative phytosociological and soil physic-chemical aspect between managed and un-managed lateritic land. Ann Forestry. 5(1): $16-25$.

Molisch, H. (1937). Der Enfusslinear pflanze andre: Allelopathie. Gustav Fischer, Jena.

Monaco, T.J., Weller, S.C. and Ashton, F.M. (2002). Weed Biology and Ecology. In: Weed Science - Principles and Practices. $4^{\text {th }}$ Ed. Pp. 13 - 43. John Wiley and Sons, Inc.

Narwal, S.S., Palaniraj, R., Sati, S.C., Kadian, H.S. and Dahiya, D.S. (2003a). Allelopathic plants: 8. Parthenium hysterophorus L. Allelopathy Journal 11(2): 151-170. 
Narwal, S.S., Palaniraj, R, Sati, S.C. and Rawat, L.S. (2003b). Effect of different parts of sunflower (Helianthus annus) biomass on wheat (Triticum aestivum). J. Ecobiol., 15: 371-376.

Navaz, M.I., Sansamma, G. and Geethakumari, V.L. (2003). Influence of Eupatorium (Chromoleana odorata L.) leachate on germination and seedling growth of rice and cowpea. Allelopathy J., 11(2): 235-240.

Nilsen, E.I. (2002). In: Inderjit and Mallik A.U. (Eds.) Birkhauser Verlag, Basel, 109-129.

Norris, R.F. (1992). Case history for weed competition/ population ecology: Barnyardgrass (Echinochloa crus-galli) in sugarbeets (Beta vulgaris). Weed Technol. 6: 220 - 227.

Orr, S.P., Rudgers, J.A. and Clay, K. (2005). Invasive plants can inhibit native tree seedlings: testing potential allelopathic mechanisms. Plant Ecol., 181: 153-165.

Pathipati Usha Rani (2008). Allelochemical stress induced biochemical changes in leaves and plant growth regulation in Ricinus communis. Allelopathy Journal 22(1): 79 -92.

Patil, T.M. and Hegde, B.A. (1988). Isolation and purification of a sequiterpene lactone from the leaves of Parthenium hysterophorus L. Its allelopathic and phytotoxic effects. Curr. Sci., 57: 1178-1181.

Pattison, R.R., Goldstein, G., Ares, A. (1998). Growth, biomass allocation and photosynthesis of invasive and native Hawaiian rainforest species. Oecologia 117: 449-459.

Pawar, K.B. and Chavan, P.D. (1999). Influence of leaf leachates of plant species on mineral nutrition of Sorghum bicolor (L.) Moench. Allelopathy Journal 6(1): 87 -92.

Pawar, K.B. (2004). Seed germination studies in Sorghum bicolor (L.) Moench. with special reference to allelopathic effects, Ph.D. thesis submitted to Shivaji University, Kolhapur, pages-253.

Ping Lu, Wei-Guo Sang and Ke-Ping Ma. (2007) Activity of Stress-related antioxidative enzymes in the Invasive Plant Crofton Weed (Eupatorium adenophorum). Journal of Integrative Plant Biology. 49 (11): 1555-1564.

Podolska, G., Bialy, Z., Jurzysta, M. and Waller, G.R. (2003). Effect of application of alfalfa root saponins aqueous solution on the plant structure, yield and quality of winter wheat. Allelopahty Journal 11(2): 171-184.

Putnam, A.R. (1985). Weed Allelopathy. In: Weed Physiol., Reproduction and Ecophysiol. (Ed., S.O. Duke, CRC press, Boca Raton, Florida, U.S.A.), 1:131-155.

Qiaoying Zhang, Shaolin Peng and Yunchun Zhang (2009). Allelopathic potential of reproductive organs of exotic weed Lantana camara. Allelopathy Journal 23(1): 213 220.

Ramadevi, S., Pellissier, F. and Prasad, M.N.V. (1997). Allelochemicals. In: Plant Ecophysiology. (Ed. M.N.V. Prasad) ISBN 0-471-13157-1 @ John Wiley and Sons, Inc.

Rao, V.S. (2000). Weed Biology and Ecology. In: Principles of Weed Science. Pp. 7 -35. Oxford and IBH Publishing Co. Pvt.Ltd.

Reigosa, M.J., Sánchez-Moreiras, A., and González, L. (1999). Ecophysiological approach in allelopathy. Crit. Rev. Plant Sci., 18(5): 577-608.

Reigosa, M. and Pedrol, N. (2002). In: Allelopathy: from Molecules to Ecosystems. Science Publishers Inc., Enfield, NH, 316p.

Rice, E.L. (1979). Allelopahty -An update. Bot. Rev., 45: 1 - 93.

Rice, E.L. (1984). “Allelopathy" 2nd Ed. Academic Press, New York, London.

Rizvi, S.J.H. and Rizvi, V. (1992). In: Allelopathy: Basic and Applied Aspects. Chapman and Hall, New York, NY, 480p. 
Ru Bai, Xin Zhao, Fengwang Ma and Cuiying Li (2009). Identification and bioassay of allelopathic substances from the root exudates of Malus prunifolia. Allelopathy Journal 23(2): 477 - 484.

Sampietro, D.A., Sgariglia, M.A., Soberon, J.R., Quiroga, E.N.and Vattuone, M.A. (2007). Role of sugarcane straw allelochemicals in the growth suppression of arrowleaf sida. Environ. Exp. Bot. 60: 495-503.

Santos, C.C., Souzaand, I.F., Alves, L.W.R. (2003). Effect of corn residues on coffee (Coffea arabica L.) growth. Cienciae Agrotochnol, 21: 991-1101.

Saswade, R.R. (2007). Allelopathic potential of some dominant weeds of semi arid crop ecosystem in Newasa Tahsil, Dist. Ahmednagar (M.S.). Ph.D. Thesis, University of Pune.

Seal, A.N., Pratley, J.E., Haig, T.J., Min An and Hanwen Wu (2009). Phytotoxic potential of Shepherd's purse on annual rye and wild radish. Allelopathy Journal 24(1): $55-66$.

Sen, D.N. (1977). Ecophysiological studies on weeds of cultivated fields with special reference to bajra (Pennisetum typhoides Rich.) and til (Sesamum indicum L.) crops. 3rd US PL - 480 Project report, Jodhpur University, Jodhpur, India. 91pp.

Sen, D.N. (1981). Ecological approaches to Indian weeds. Geobios International, Jodhpur, India. pp. 301.

Serraj, R. and Sinclair, T. R. (2002). Osmolyte accumulation: can it really help increase crop yield under drought conditions? Plant Cell Environ. 25: 333 - 341.

Singh, D. and NarsingRao, Y.B. (2003). Allelopathic evaluation of Andrographis paniculata aqueous leachates on rice (Oryza sativa L.). Allelopathy Journal 11(1): 71-76.

Singh, N.B. and Singh, R. (2003). Effect of leaf leachate of Eucalyptus on germination, growth and metabolism of greengram, blackgram and peanut. Allelopathy Journal 11(1): 4352.

Stevens, O.A. (1957). Weights of seeds and numbers per plant. Weeds 5: $46-55$.

Sutherland, S. (2004). What makes a weed a weed: life history traits of native and exotic plants in the USA. Population Ecology. 141: 24 - 39.

Takeuchi, Y., Kawaguchi, S. and Yoneyama, K.F. (2001). Inhibitory and promontory allelopathy in rice (Oryza sativa L.) Weed Biology and Management 1: 147 - 156.

Tambussi, E.A., Bartoli, C.G., Beltrano, J., Guiamet, J.J., Araus, J.L. (2000). Oxidative damage to thylakoid proteins in water stressed leaves of wheat (Triticum aestivum). Physiol Planta. 108: 398-404. DOI : 10.1034/j.1399-3054.2000.108004398.

Tanaka, K. (1994). Tolerance to herbicides and air pollutants. In: Causes of Photooxidative Stress and Amelioration of Defense Systems in Plants. (Foyer C.H., Mullineaux P.M. eds.) pp. 365- 378. CRC Press, Boca Raton.

Thakur, A.S. and Khare, P.K. (2009). Composition of forest vegetation and floristics of Sagar district, central India. J. Ind. Bot. Soc. 88(1 \& 2): 11 - 17.

Vaidya, R.R. (2009). Allelopathic studies in some dominant plants from Mahabaleshwar area. Ph.D. Thesis, University of Pune.

Varadpande, D.G. (1972). Flora of Ganeshkhind. University of Pune, Pune, India.

Vilai-Santisopasri (2003). Kasetsart University research and development Institute, Bangkok, Thailand.

Venkatesan, A. and Chellappan, K.P. (1998). Accumulation of praline and glycine betaine in Ipomoea pescaprae induced by $\mathrm{NaCl}$. Biol Planta 41: 271-276. DOI : 10.1023/ A:1001839302627 
Wang, P., Qin, Z.Q., Wang, P. and Zhao, Z.Q. (2001). Effect of allelochemical on cotton seed germination and seedling growth. J. China Agri. Univ., 6: 26-31.

Wang, J., Feng, Y. and Liang, H. (2004). Adaptation of Eupatorium adenophorum photosynthetic characteristics to light intensity. Yingy Sheng. Xueb., 15(8):1373-1377.

Weaver, S.E., McWilliams, E.L. (1980). The biology of Canadian weeds. 44. Amaranthus retroflexus L. and A. powellii S. and A. hybridus L. Can J Plant Sci. 60:1215 - 1234.

Werner, P.A. and Soule, J.D. (1976). The biology of Canadian weeds. 18. Potentilla recta L., $P$. norvegica L. and P. argena L. Can J Plant Sci 56: 591 - 603.

Wilson, R. G. (1988). Biology of weeds in the soil. In: Altieri MA., Liebman M, (eds.) Weed management in agroecosystems: ecological approaches. pp. 25 - 39.Boca Raton, FL: CRC Press.

Yang, X. and Lu, C. (2005). Photosynthesis is improved by exogenous glycine betaine in salt-stressed maize plants. Physiol Planta. 124: 343-352. DOI : 10.1111/j.13993054.2005.00518.

Yang, G.Q., Liu, W.X., Zhang, X.W. (2006). Physiological effects of allelochemicals from leachates of Ageratina adenophora (Spreng.) on rice seedlings. Allelopathy Journal 18(2): 237-246.

Young, J.A. (1991). Tumbleweed. Sci. Am. March: 82 - 87.

Zhu, J. K. (2002). Salt and drought stress signal transduction in plants. Ann. Rev.Plant physiol. Plant Mol. Biol. 53: 247 - 273.

Zouhar, K. (2003). Potentilla recta Vol. 2003. U.S. Department of Agriculture, Forest service, Rocky Mountain Research Station, Fire Sciences Laboratory, Missoula, MT. 


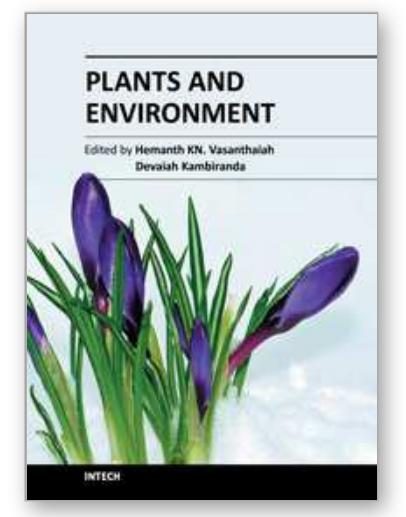

\author{
Plants and Environment \\ Edited by Dr. Hemanth Vasanthaiah
}

ISBN 978-953-307-779-6

Hard cover, 272 pages

Publisher InTech

Published online 17, October, 2011

Published in print edition October, 2011

Changing environmental condition and global population demands understanding the plant responses to hostile environment. Significant progress has been made over the past few decades through amalgamation of molecular breeding with non-conventional breeding. Understanding the cellular and molecular mechanisms to stress tolerance has received considerable scientific scrutiny because of the uniqueness of such processes to plant biology, and also its importance in the campaign â€œFreedom From Hungerâ€. The main intention of this publication is to provide a state-of-the-art and up-to-date knowledge of recent developments in understanding of plant responses to major abiotic stresses, limitations and the current status of crop improvement. A better insight will help in taking a multidisciplinary approach to address the issues affecting plant development and performance under adverse conditions. I trust this book will act as a platform to excel in the field of stress biology.

\title{
How to reference
}

In order to correctly reference this scholarly work, feel free to copy and paste the following:

Nivedita Ghayal and Kondiram Dhumal (2011). Morphophysiological Investigations in Some Dominant Alien Invasive Weeds, Plants and Environment, Dr. Hemanth Vasanthaiah (Ed.), ISBN: 978-953-307-779-6, InTech, Available from: http://www.intechopen.com/books/plants-and-environment/morphophysiological-investigationsin-some-dominant-alien-invasive-weeds

\section{INTECH}

open science | open minds

\author{
InTech Europe \\ University Campus STeP Ri \\ Slavka Krautzeka 83/A \\ 51000 Rijeka, Croatia \\ Phone: +385 (51) 770447 \\ Fax: +385 (51) 686166 \\ www.intechopen.com
}

\author{
InTech China \\ Unit 405, Office Block, Hotel Equatorial Shanghai \\ No.65, Yan An Road (West), Shanghai, 200040, China \\ 中国上海市延安西路65号上海国际贵都大饭店办公楼 405 单元 \\ Phone: +86-21-62489820 \\ Fax: $+86-21-62489821$
}


(C) 2011 The Author(s). Licensee IntechOpen. This is an open access article distributed under the terms of the Creative Commons Attribution 3.0 License, which permits unrestricted use, distribution, and reproduction in any medium, provided the original work is properly cited. 